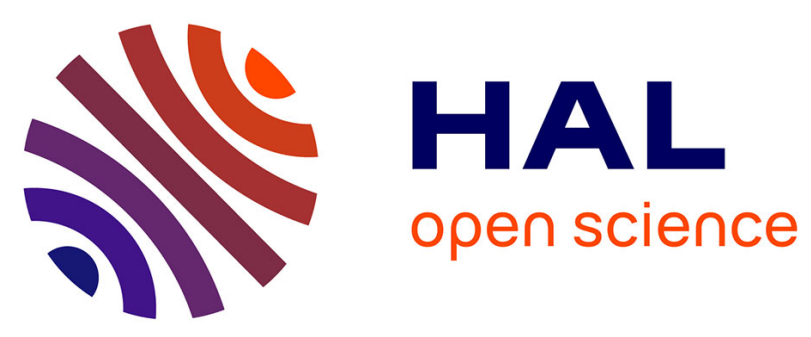

\title{
Anticancer Properties of Indole Derivatives as IsoCombretastatin A-4 analogues
}

Shannon Pecnard, Abdallah Hamze, Jérome Bignon, Bastien Prost, Alain Deroussent, Laura Gallego-Yerga, Rafael Peláez, Ji Yeon Paik, Marc Diederich, Mouâd Alami, et al.

\section{To cite this version:}

Shannon Pecnard, Abdallah Hamze, Jérome Bignon, Bastien Prost, Alain Deroussent, et al.. Anticancer Properties of Indole Derivatives as IsoCombretastatin A-4 analogues. European Journal of Medicinal Chemistry, 2021, 223, pp.113656. 10.1016/j.ejmech.2021.113656 . hal-03349143

\section{HAL Id: hal-03349143 \\ https://hal.science/hal-03349143}

Submitted on 20 Sep 2021

HAL is a multi-disciplinary open access archive for the deposit and dissemination of scientific research documents, whether they are published or not. The documents may come from teaching and research institutions in France or abroad, or from public or private research centers.
L'archive ouverte pluridisciplinaire HAL, est destinée au dépôt et à la diffusion de documents scientifiques de niveau recherche, publiés ou non, émanant des établissements d'enseignement et de recherche français ou étrangers, des laboratoires publics ou privés. 


\title{
Anticancer Properties of Indole Derivatives as IsoCombretastatin A-4 analogues
}

Shannon Pecnard, ${ }^{\mathrm{a}}$ Abdallah Hamze, ${ }^{\mathrm{a}}{ }^{\mathrm{a}}$ Jérome Bignon, $^{\mathrm{b}}$ Bastien Prost, ${ }^{\mathrm{c}}$ Alain Deroussent ${ }^{\mathrm{d}}$ Laura Gallego-Yerga, ${ }^{\mathrm{e}}$ Rafael Peláez, ${ }^{\mathrm{e}} \mathrm{Ji}$ Yeon Paik, ${ }^{\mathrm{f}}$ Marc Diederich, ${ }^{\mathrm{f}}$ Mouad Alami, ${ }^{\mathrm{a}}$ and Olivier Provot* $*^{\mathrm{a}}$

${ }^{a}$ Université Paris-Saclay, CNRS, BioCIS, 92290, Châtenay-Malabry, France.

${ }^{b}$ Institut de Chimie des Substances Naturelles, UPR 2301, CNRS avenue de la terrasse, F-91198 Gif sur Yvette, France.

${ }^{c}$ Service d'Analyse des Médicaments et Métabolites, IPSIT, Univ. Paris-Sud, UMS 3679 CNRS, US 31 INSERM, Université ParisSaclay, 92290 Châtenay Malabry, France.

${ }^{d}$ Metabolic and Systemic aspects of oncogenesis (METSY), UMR 9018, CNRS, Institut Gustave Roussy, Université Paris-Saclay, 94805 Villejuif. France.

${ }^{e}$ Laboratorio de Química Orgánica y Farmacéutica, Departamento de Ciencias Farmacéuticas, Facultad de Farmacia, Universidad de Salamanca, Salamanca, Spain.

${ }^{f}$ Department of Pharmacy, College of Pharmacy, Seoul National University, 1 Gwanak-ro, Gwanak-gu, Seoul 08626, Korea.

*Corresponding authors. Tel.: +331468358 47. Fax: +331468358 28. Email: olivier.provot@universite-paris-saclay.fr mouad.alami@universite-paris-saclay.fr and abdallah.hamze@ universite-paris-saclay.fr

\begin{abstract}
In this study, a variety of original ligands related to Combretastatin A-4 and isoCombretastatin A-4, able to inhibit the tubulin polymerization into microtubules, was designed, synthesized, and evaluated. Our lead compound 15d having a quinazoline as A-ring and a 2-substituted indole as B-ring separated by a $N$-methyl linker displayed a remarkable subnanomolar level of cytotoxicity $\left(\mathrm{IC}_{50}<1 \mathrm{nM}\right)$ against 9 human cancer cell lines.
\end{abstract}

Keywords: Cancer, cytotoxicity, indole, isoCA-4, oxazinoindole, pyridoindole, quinazoline, tubulin. 


\section{Introduction}

Isolated from the African willow tree, Combretum caffrum by G. Pettit[1] in 1989, Combretastatin A-4 (CA-4 1, Figure $1)$ is a very potent cytotoxic agent having nanomolar $\mathrm{IC}_{50}$ values against many human cancer cell lines.[2] This (Z)stilbene acts by binding to the colchicine site on $\beta$-tubulin, thus interrupting the polymerization of tubulin into microtubules.[3] Moreover, it has been demonstrated that a moderate single dose of CA-4P 2, a water-soluble phosphate pro-drug of CA-4, causes almost complete cessation of the blood circulation in tumour vessels without vascular damage in normal cells.[4,5,6] This discovery was the source of a spectacular craze from the scientific community for this small molecule which was then the subject of numerous structure-activity relationships studies.[7,8,9] The majority of these structural modifications consisted in introducing the $(Z)$-double bond into cyclic or heterocyclic systems since it has been shown that, despite its pronounced efficacy in clinical trials, the $(Z)$-double bond of CA-4 isomerizes during storage, administration and metabolism leading to the more stable but less active E-isomer.[10,11,12] In the continuation of our work dedicated to the synthesis of non-isomerizable analogues of CA-4[13], we discovered that the stable synthetic compound isoCA-4 3, displayed the same anti-cancer activities as its natural isomer CA-4 but without the risk of isomerization.[14,15,16,17] We next demonstrated that several modifications of the phenolic B-ring of CA-4 and isoCA-4 were authorized by introducing, for example $-\mathrm{NH}_{2}$, -alkynes, -alkenyl groups, or a fluorine atom in place of the C3'-OH substituent.[18,19] We and the Pinney's group have also showed that the ethylene double bond of isoCA-4 can be reduced[20] or inserted into cycles and heterocycles[21,22,23,24,25,26] without loss of anti-cancer properties. Structure-activity relationships (SARs) also revealed that various non-isomerizable linkers of small size are welcome[13] of which the $N$-Methyl group predominated (e.g., azaFisoerianin 4).[27] Finally, it was demonstrated that the classical 3,4,5-trimethoxyphenyl (TMP) A-ring of CA-4 and isoCA-4 could be advantageously replaced by heterocycles as quinazolines[28] or quinolines[29] to promote highly cytotoxic analogues 6[30] and 7[31] having in structures a carbazole nucleus as B-ring. Herein, we were interested in synthesizing and evaluating the cytotoxicity of target molecules of type pyrido[1,2-a]indoles 11[32] depicted in Scheme 1, which could be seen as analogues of carbazole compounds 5-7[33,34] by connecting the nitrogen atom N1 to the carbon atom C2 in the carbazole system. We will also evaluate the cytotoxicity of their 6,9-dihydropyrido[1,2-a]indole precursors $\mathbf{1 0}$ to understand the structureactivity relationships (SARs) better. Next, the insertion of an oxygen atom in the pyridine part of the pyrido[1,2a]indoles ring of compounds 11 leading to oxazino[4,3-a]indoles 12 (Scheme 2) and their "opened" analogues 15 (Schemes 3 and 4) will be presented by establishing a comprehensive SAR study.
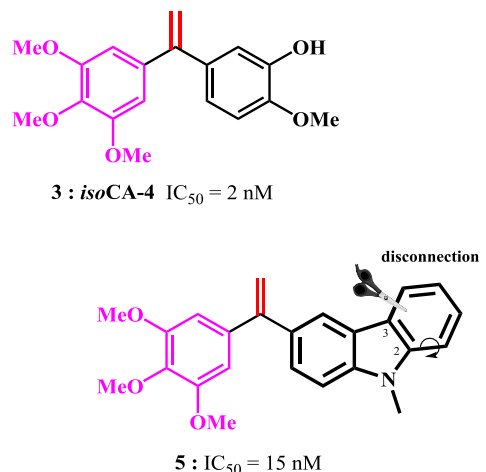
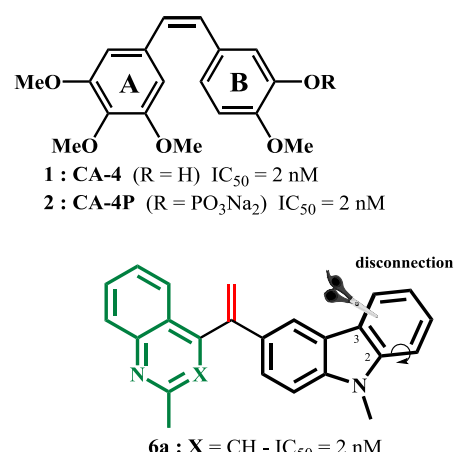

6b : $\mathbf{X}=\mathrm{N}-\mathrm{IC}_{50}=40 \mathrm{nM}$
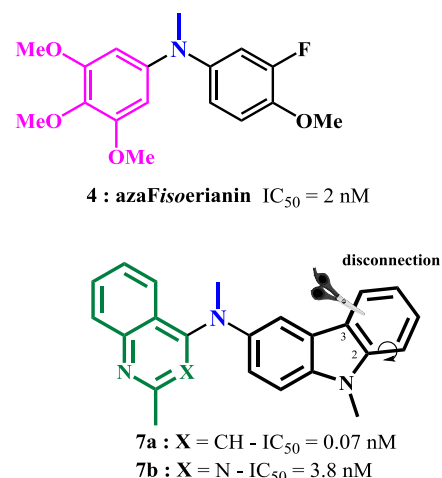

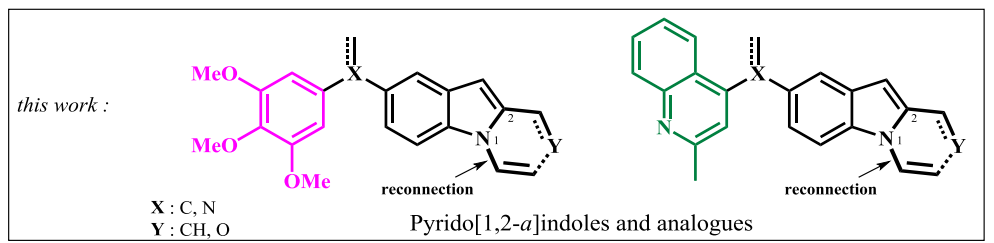

Figure 1. Structures of CA-4 1, CA-4P 2 and a selection of analogues 3-7 accompanied by target molecules pyrido[1,2a]indoles. 


\section{Results and discussion}

\subsection{Chemistry.}

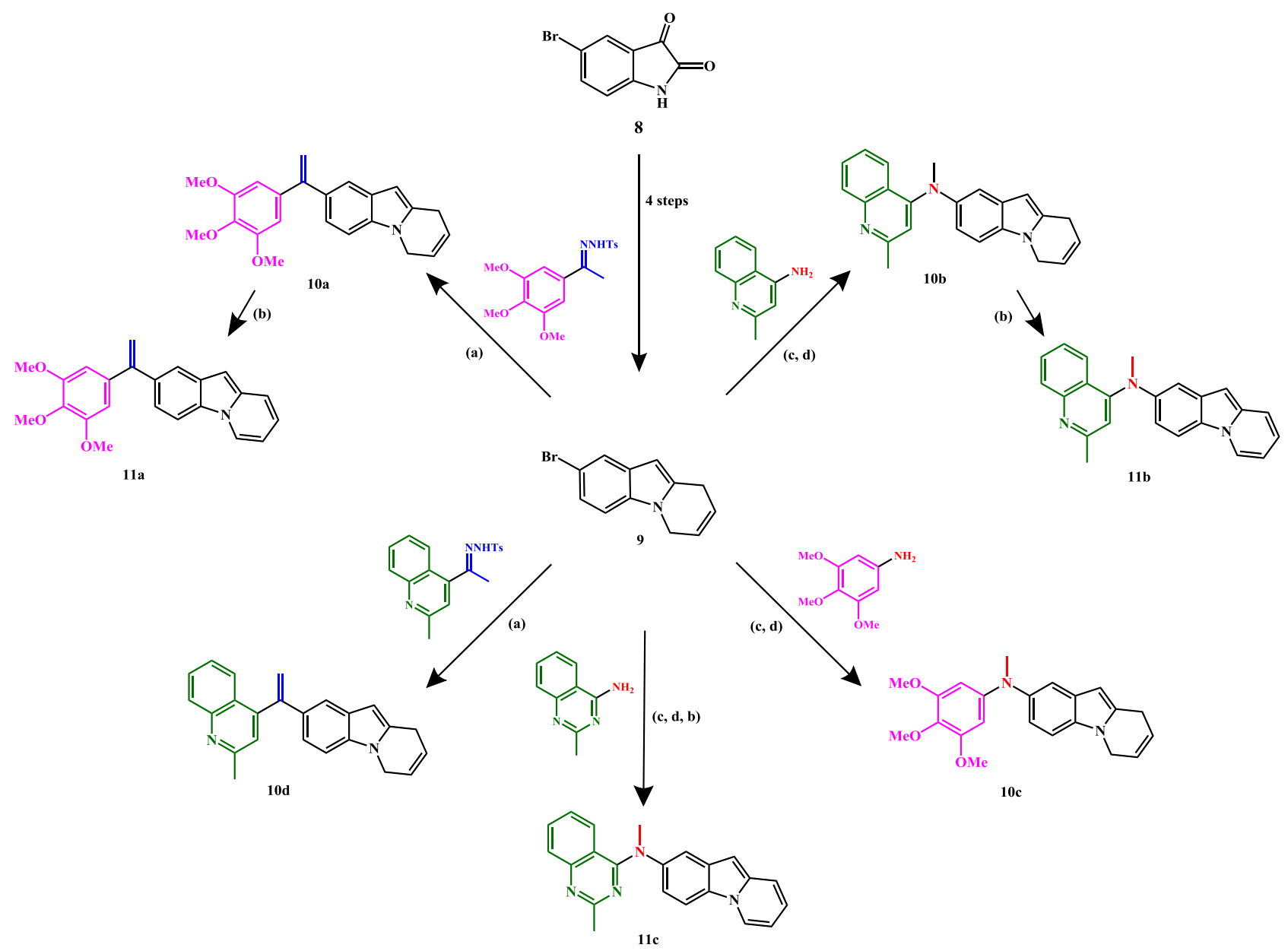

Reagents and conditions: (a) $\mathrm{Pd}_{2} \mathrm{dba}_{3} \cdot \mathrm{CHCl}_{3}$, XPhos, $\mathrm{LiOtBu}$, dioxane, $100{ }^{\circ} \mathrm{C}$. (b) $\mathrm{Pd} / \mathrm{C} 10 \mathrm{~mol} \%$, xylene, $145{ }^{\circ} \mathrm{C}, 24$ h. (c) $\mathrm{Pd}_{2} \mathrm{dba}_{3} \cdot \mathrm{CHCl}_{3}, \mathrm{XPhos}$, $\mathrm{NaO} t \mathrm{Bu}$, dioxane, $100{ }^{\circ} \mathrm{C}$. (d) $\mathrm{NaH}, \mathrm{CH}_{3} \mathrm{I}, \mathrm{DMF}$, rt.

Scheme 1. Synthesis of targets pyridinoindoles 11a-c and reduced analogues 10a-d.

To synthesize 6,9-dihydropyridino[1,2-a]indoles $\mathbf{1 0}$ and pyridino[1,2-a]indole targets 11, we first prepare the brominated building block 9 as the key intermediate starting from 5-bromoisatin in four steps (Scheme 1).[35] Compound 11a was obtained in two steps from the coupling reaction between 9 and the $N$-tosylhydrazone of 3,4,5trimethoxyphenylacetophenone to provide 10a.[36] Then, 6,9-dihydropyrido[1,2-a]indole 10a was oxidized into 11a using $\mathrm{Pd} / \mathrm{C}$ in hot xylene. Amino derivative 11b was obtained from 9 which was successfully coupled with 4aminoquinaldine to give after a $N$-methylation reaction $\mathbf{1 0 b}$ finally oxidized into pyridino[1,2-a]indole $\mathbf{1 1 b}$. The brominated platform 9 was also successfully used to provide in two steps 10c and 10d in a similar manner as described for above for $\mathbf{1 0 b}$ and $\mathbf{1 0 a}$ respectively. Finally, quinazoline derivative 11c bearing a pyridino[1,2-a]indole B-ring, a quinazoline A-ring and a $N$-methyl group as linker was prepared in three steps from 4-aminoquinazoline and 9 under Buchwald-Hartwig conditions without isolating the synthetic intermediates which revealed to be partially unstable on silica gel column.

Next, we prepared a series of 3,4-dihydro-1H-[1,4]oxazino[4,3-a]indoles 12a-g having a $N$-methyl or an ethylene linker and various A-ring as quinolines, quinazolines and the traditional 3,4,5-trimethoxyphenyl ring. (Scheme 2). The key brominated intermediate 8-bromo-3,4-dihydro-1 $H$-[1,4] oxazino[4,3-a]indole 13, useful for coupling reactions, was prepared from indole 14a according to a slightly modified procedure described by Chen and Xiao.[37] By replacing 


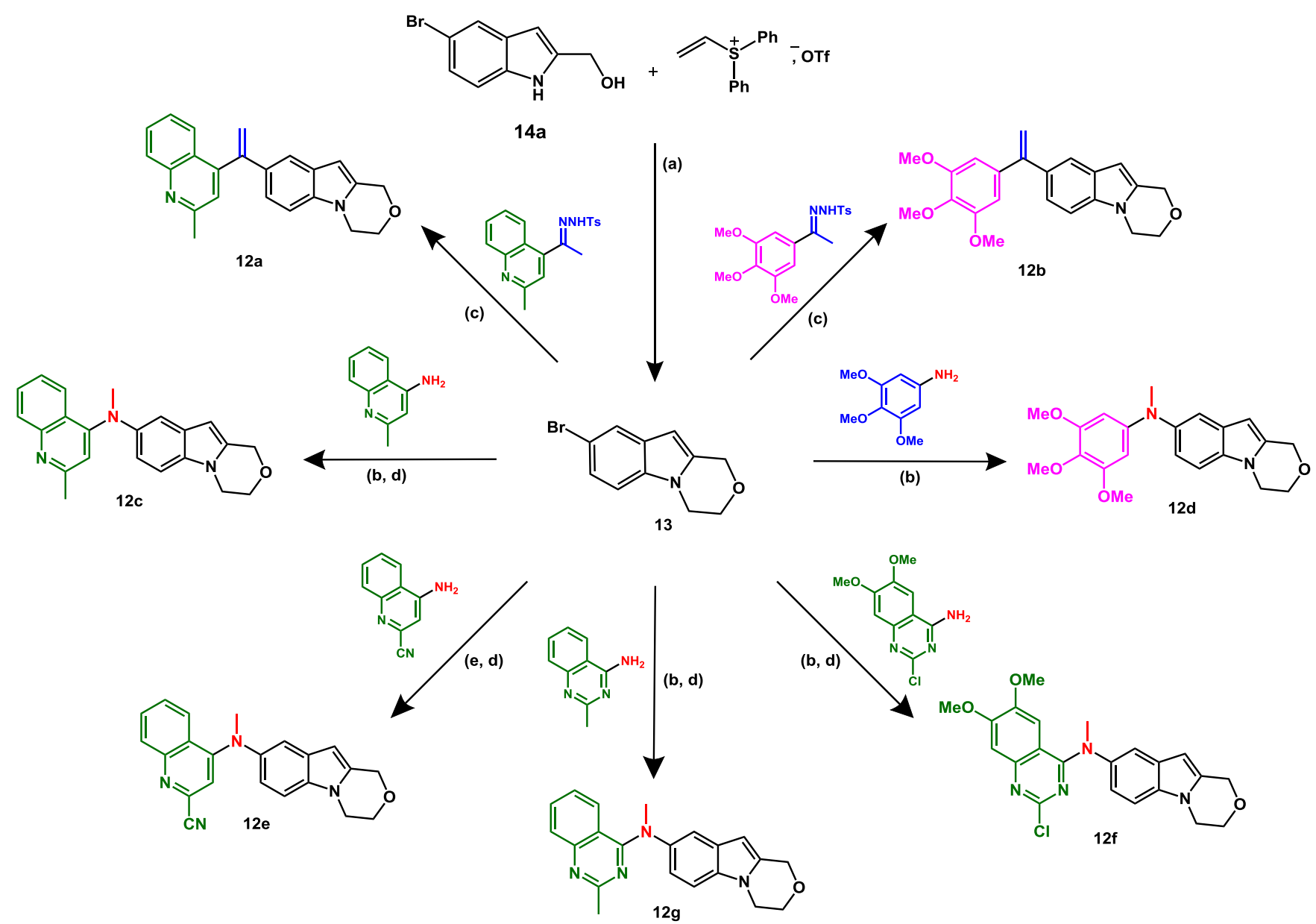

Reagents and conditions: (a) NaH, fluorobenzene, rt, 30 min. (b) $\mathrm{Pd}_{2} \mathrm{dba}_{3} \cdot \mathrm{CHCl}_{3}, \mathrm{XPhos}, \mathrm{NaOtBu}$, dioxane, $100{ }^{\circ} \mathrm{C}$. (c) $\mathrm{Pd}_{2} \mathrm{dba}_{3} \cdot \mathrm{CHCl}_{3}, \mathrm{XPhos}$ LiO $t \mathrm{Bu}$, dioxane, $100{ }^{\circ} \mathrm{C}$. (d) $\mathrm{NaH}, \mathrm{CH}_{3} \mathrm{I}$, DMF, rt. (e) $\mathrm{Pd}_{2} \mathrm{dba}_{3} \cdot \mathrm{CHCl}_{3}, \mathrm{XPhos}, \mathrm{Cs}_{2} \mathrm{CO}_{3}$, dioxane, $100{ }^{\circ} \mathrm{C}$.

Scheme 2. Synthesis of targets 3,4-dihydro-1H-[1,4]oxazino[4,3-a]indoles 12a-g.

$\mathrm{KOH}$ with $\mathrm{NaH}$ as the base and $\mathrm{CH}_{2} \mathrm{Cl}_{2}$ by fluorobenzene as the solvent, the reaction between (5-bromo- $1 \mathrm{H}$-indol-2yl)methanol 14a and diphenyl vinyl sulfonium triflate led to $\mathbf{1 3}$ in only 30 min with a $92 \%$ yield (for comparison when using $\mathrm{KOH}$ in $\mathrm{CH}_{2} \mathrm{Cl}_{2}, 13$ was obtained after $10 \mathrm{~h}$ of reaction with a $76 \%$ yield). Then, 8-bromo-3,4-dihydro- $1 \mathrm{H}$ [1,4] oxazino[4,3-a]indole $\mathbf{1 3}$ was successfully coupled with hydrazino derivatives under Pd-catalysis to give 12a and 12b with good yields ( $82 \%$ and $62 \%$, respectively). For the synthesis of compound $12 \mathrm{e}$ having a nitrile group, the same catalytic system was used as before but $\mathrm{Cs}_{2} \mathrm{CO}_{3}$ was employed as a base instead of $\mathrm{LiO} t \mathrm{Bu}$ to avoid a $\mathrm{CN}$-hydration reaction.[38] The tertiary amines $\mathbf{1 2 c}$-g were obtained after a $N$-methylation reaction (without isolating the intermediate secondary diarylamines) with variable yields (from $30 \%$ to $75 \%$ for the two steps).

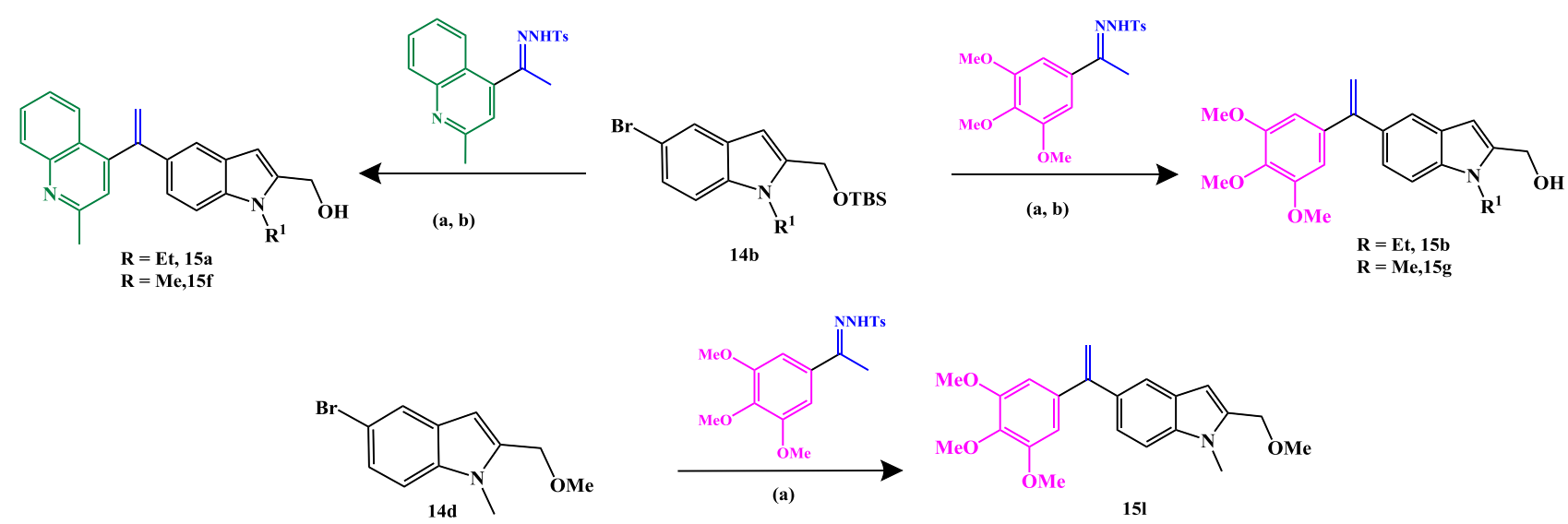

(a) $\mathrm{Pd}_{2} \mathrm{dba}_{3} \cdot \mathrm{CHCl}_{3}$, XPhos, $\mathrm{LiO} t \mathrm{Bu}$, dioxane, $100{ }^{\circ} \mathrm{C}$. (b) TBAF, THF, rt.

Scheme 3. Synthesis of target indole compounds $\mathbf{1 5}$ having an ethylene linker. 
We also prepared for biological comparisons, a series of 1,2-disubstituted indole derivatives 15a-l as "opened analogues" of oxazino[4,3-a]indoles 12 (Schemes 3 and 4). Diarylethylene compounds 15a,b and 15f,g were prepared in two steps from the Barluenga's coupling reactions between the brominated platforms $\mathbf{1 4 b}$ or $\mathbf{1 4} \mathbf{c}$ with the required $N$ tosylhydrazones followed by a $O$-desylilation reaction using TBAF in THF (Scheme 3). Diarylmethylamines $\mathbf{1 5 c - e}$ were prepared in three steps according to a Buchwald coupling reaction using above reaction conditions with 14b and $\mathrm{N}$-ethylindoles, and the required secondary amines were then $\mathrm{N}$-methylated and $\mathrm{O}$-deprotected without prior purification (Scheme 4). $\mathrm{N}$-methylindole 15h having on $\mathrm{C} 2$ a $\mathrm{CH}_{2} \mathrm{OH}$-substituent was prepared similarly after a three steps sequence (Buchwald-Hardwig coupling, $N$-methylation and desilylation). $N$-methylindoles $\mathbf{1 5 j}$,k having on $\mathrm{C} 2$ a $\mathrm{CH}_{2} \mathrm{OMe}$ group were prepared according to a Buchwald-Harding coupling reaction followed by a $N$-methylation reaction as above. Finally, indole derivative 15i having on $\mathrm{C} 2$ a $\mathrm{CH}_{2} \mathrm{OMOM}$-group was prepared in two steps from 5bromo-2-(methoxymethyl)-1-methyl- $1 H$-indole 14e and 4-aminoquinaldine. It is important to note that all secondary amine and silylated intermediates were used without needing to be purified.
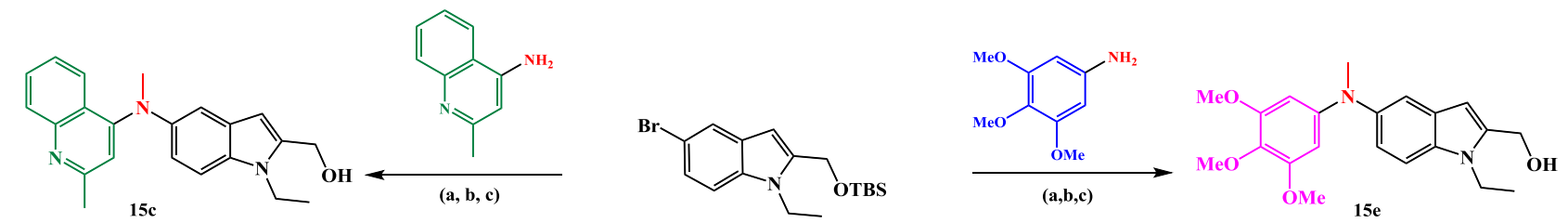

15
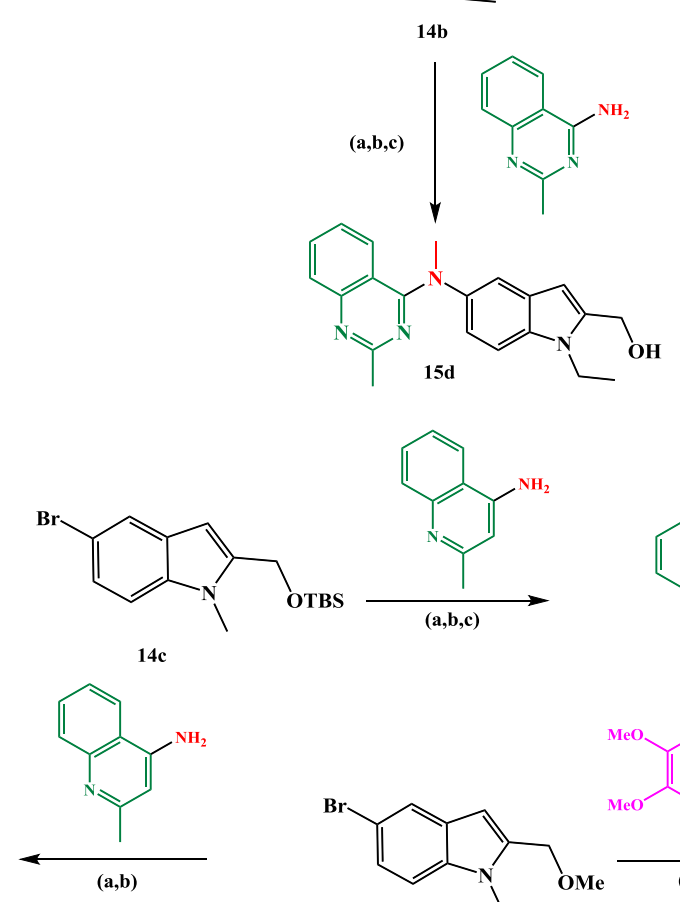

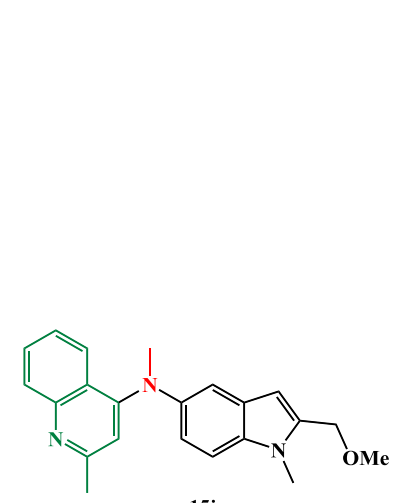

$15 \mathbf{j}$

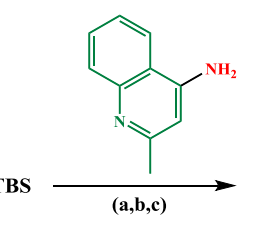

$5 \mathrm{e}$ 
Table 1 Cytotoxicity against HCT116 cells ${ }^{a}$ and ITP of new compounds 10, 11, 12 and 15.

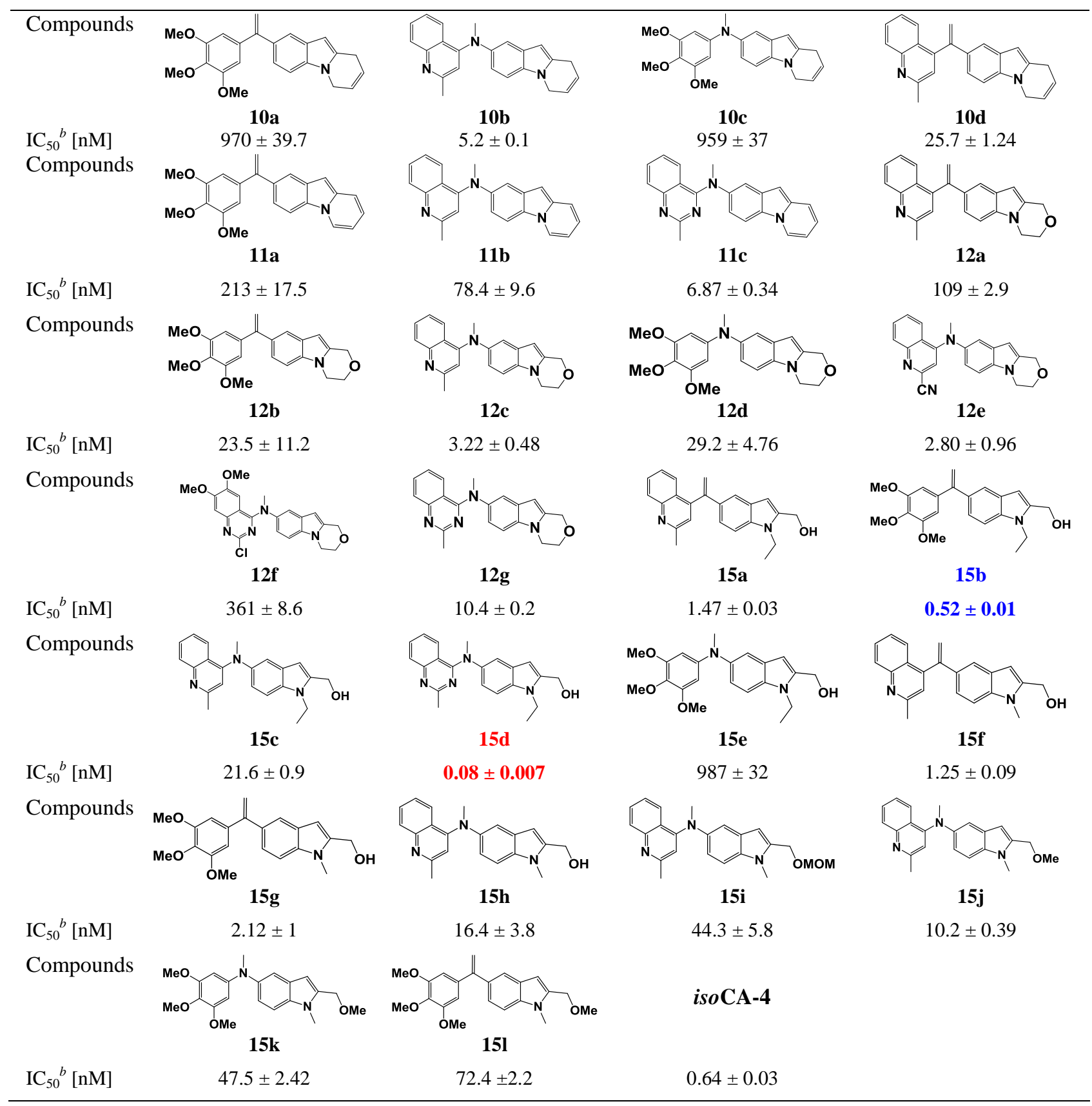

${ }^{a} \mathrm{HCT} 116$ human colon carcinoma ${ }^{b} \mathrm{IC}_{50}$ is the concentration of compound needed to reduce cell growth by $50 \%$ following $72 \mathrm{~h}$ cell treatment with the tested drug (average of three experiments).

carcinoma (HCT116) cell line. A fluorimetry-based assay was used to determine of the drug concentration required to inhibit cell growth by $50 \%$ after incubation in the culture medium for 72 h. IsoCA-4[39] was included as the reference compound for comparisons. Examination of compounds 10a-d in which the 6,9-dihydropyridino[1,2-a]indole B-ring was constant showed that derivative $\mathbf{1 0 b}\left(\mathrm{IC}_{50}=5.2 \mathrm{nM}\right)$ having a quinoline as A-ring and a $N$-Methyl linker was undoubtedly the most active compound in this series. Replacing the quinoline with the isosteric TMP nucleus considerably reduced the cytotoxicity level against HCT116 cancer cells $\left(\mathbf{1 0 c}, \mathrm{IC}_{50}=959 \mathrm{nM}\right)$, similarly, the replacement of the $N$-methyl linker present in $\mathbf{1 0 b}$ by a 1,1-ethylene linker decreased cytotoxicity by a five-fold factor $\left(\mathbf{1 0 d}, \mathrm{IC}_{50}=25.7 \mathrm{nM}\right)$. Pyrido[1,2- $a$ ]indoles 11a-c, which were the first compounds targeted in this study as structural analogues of carbazoles (Figure 1) displayed varying toxicity levels. Comparison of $\mathbf{1 1 b}\left(\mathrm{IC}_{50}=78.4 \mathrm{nM}\right)$ with $\mathbf{1 0 b}$ $\left(\mathrm{IC}_{50}=5.2 \mathrm{nM}\right)$ showed that the aromatization of the 6,9-dihydropyridino[1,2-a]indole nucleus decreased the cytotoxicity level. We can also note that pyrido[1,2-a]indole 11b was found to be significantly less cytotoxic than its 
carbazole analogue 7b.[29] However, we were pleased to observe that, in the pyrido[1,2-a]indoles series, the quinaldine A-ring replacement with a quinazoline motif increased the cytotoxic activity 11 -fold (compare 11b with 11c). Next, compounds 12a-g were examined and compared from a biological point of view. Again, in this class of compounds having a 3,4-dihydro- $1 H$-[1,4] oxazino[4,3-a]indole as B-ring, the two more potent drugs $\mathbf{1 2 c}\left(\mathrm{IC}_{50}=3.22 \mathrm{nM}\right)$ and $\mathbf{1 2 e}$ $\left(\mathrm{IC}_{50}=2.80 \mathrm{nM}\right)$ have in structure a 2-substituted quinoline as ring $\mathrm{A}$ and an $N$-methyl linker. Examining the cytotoxicity level of $\mathbf{1 2} \mathbf{g}\left(\mathrm{IC}_{50}=10.4 \mathrm{nM}\right)$ revealed that a 2-methylquinazoline nucleus as A-ring was also welltolerated in this series. The replacement of these heterocycles by the "classical" TMP A-ring present in $\mathbf{1 2 b}\left(\mathrm{IC}_{50}=23.5\right.$ $\mathrm{nM})$ and 12d $\left(\mathrm{IC}_{50}=29.2 \mathrm{nM}\right)$ caused a slight decrease in cytotoxicity against HCT116 cells. Finally, results depicted in Table 1 suggest that compounds 15 having a 2-substituted indole as B-ring are the more cytotoxic compounds of this study, with five compounds displaying a cytotoxicity level ranging from $0.08 \mathrm{nM}$ to $2.12 \mathrm{nM}$. Examination of Table 1 also revealed that compounds having as B-ring a C2-hydroxymethylindole and an ethylene linker tolerated well as Aring a quinaldine $\left(\mathbf{1 5 a} \mathrm{IC}_{50}=1.47 \mathrm{nM}\right)$ or a TMP nucleus $\left(\mathbf{1 5 b} \mathrm{IC}_{50}=0.52 \mathrm{nM} ; \mathbf{1 5 g} \mathrm{IC}_{50}=2.12 \mathrm{nM}\right)$. With compounds having the same indolic B-ring and a $N$-methyl linker, results depicted in Table 1 showed that the best A-ring was a quinazoline, with our lead compound 15d having a remarkable $\mathrm{IC}_{50}$ value of $0.08 \mathrm{nM}$. The replacement of a quinazoline by a quinaldine in these compounds led to a slight decrease in cytotoxicity $\left(\mathbf{1 5 c} \mathrm{IC}_{50}=21.6 \mathrm{nM} ; \mathbf{1 5 h} \mathrm{IC}_{50}=16.4 \mathrm{nM}\right)$ and led to a dramatic loss of activity by changing these heterocycles by a TMP ring $\left(\mathbf{1 5 e} \mathrm{IC}_{50}=978 \mathrm{nM}\right)$.[40] Comparison of the cytotoxicity level of compounds $\mathbf{1 5 h}, \mathbf{1 5 i}$ and $\mathbf{1 5} \mathbf{j}$ revealed that the methylation of the alcohol function led to equipotent drugs (compare $\mathbf{1 5 h} \mathrm{IC}_{50}=16.4 \mathrm{nM}$ and $\mathbf{1 5} \mathbf{j} \mathrm{IC}_{50}=10.2 \mathrm{nM}$ ) whereas a $-\mathrm{CH}_{2} \mathrm{OMOM}$ substituent on $\mathrm{C} 2$ of the indole decreased the activity $\left(\mathbf{1 5 i} \mathrm{IC}_{50}=44.3 \mathrm{nM}\right)$. In this preliminary screening, we found 16 compounds of different structures having a cytotoxicity level inferior to $30 \mathrm{nM}$. Before studying the mechanism of action of the most promising compounds in this series, we performed comparative metabolization studies of the two most cytotoxic compounds $\mathbf{1 5 b}$ and $\mathbf{1 5 d}$ against HCT116 cells in the presence of rats and human microsomes.

\subsubsection{In vitro metabolisation study of $\mathbf{1 5 b}$ and $\mathbf{1 5 d}$ vs isoCA-4.[17]}

\subsubsection{Characterization of $\mathbf{1 5 d}, \mathbf{1 5 b}$, isoCA-4 and metabolites by HPLC-MS.}

High resolution electrospray mass spectra $\left(\mathrm{HRMS}_{\mathrm{ESI}}{ }^{+}\right)$of compounds $\mathbf{1 5} \mathbf{b}, \mathbf{1 5} \mathbf{d}$ and isoCA-4 provided their protonated molecular ions $[\mathrm{M}+\mathrm{H}]^{+}$at $m / z 347.1863$ (347.1872 calculated for $\mathrm{C}_{21} \mathrm{H}_{23} \mathrm{~N}_{4} \mathrm{O}$ ), $\mathrm{m} / z 368.1854$ (368.1862 calculated for $\mathrm{C}_{22} \mathrm{H}_{26} \mathrm{NO}_{4}$ ) and $\mathrm{m} / z 317.1384$ (317.1389 calculated for $\mathrm{C}_{18} \mathrm{H}_{21} \mathrm{O}_{5}$ ), respectively. After $96 \mathrm{~h}$ incubation with rat or human liver microsomes, compound 15d could produce minor $N$-demethylated metabolites and hydroxylated metabolites, although 15b compound and isoCA-4 were mainly metabolized into $O$-demethylated (M-14) and hydroxylated metabolites as described before.[30]

\subsubsection{Microsomal stability of studied compounds}

To determine their metabolic stability, expressed as the percentage $(\%)$ of remaining parent compound concentration over time, kinetic monitoring was performed by HPLC-MS/MS of independent incubations of each compound with rat liver microsomes (RLM) and human liver microsomes (HLM). Concentrations of each compound in microsomal incubations were backcalculated using their calibration curves. After quantification of the ratio of the residual concentration to its initial value, the half-life time was $18 \mathrm{~h}$ for $i s o \mathrm{CA}-4,70 \mathrm{~h}$ for $\mathbf{1 5 b}$, and $140 \mathrm{~h}$ for $\mathbf{1 5 d}$ with rat liver microsomes (Table 2). The half-life time was $30 \mathrm{~h}$ for isoCA-4, $89 \mathrm{~h}$ for $\mathbf{1 5 b}$ and $145 \mathrm{~h}$ for $\mathbf{1 5 d}$ with human liver microsomes (as shown in Table 2). It is of note that these in vitro $\mathrm{t}^{1 / 2}$ values for each drug are observed in good agreement between rat and human liver microsomes. The natural logarithms (ln) of the remaining concentrations (\%) were plotted against incubation times (Figures $2 \mathrm{a}$ and $2 \mathrm{~b}$ ). Using the value 3.912 of (ln 50), the in vitro half-lives ( $\mathrm{t} 1 / 2$ ) were found with HLM in the following ascending order, isoCA-4 $<\mathbf{1 5 b}<\mathbf{1 5 d}$, in agreement with this obtained with 
Table 2. Metabolic stability of isoCA-4, quinazoline 15d and 15b in rat liver microsomes (RLM) and human liver microsomes (HLM)

Half-life time $(\mathrm{h})^{a}$
(Rat liver microsomes)

${ }^{a}$ The metabolic stability is expressed as the in vitro half-life time, based on the 3,912 value (ln 50) corresponding to the remaining concentration.

RLM. However, a slower metabolism was observed with HLM than with RLM. The quinazoline compound 15d showed the best metabolic stability when compared with isoCA-4.

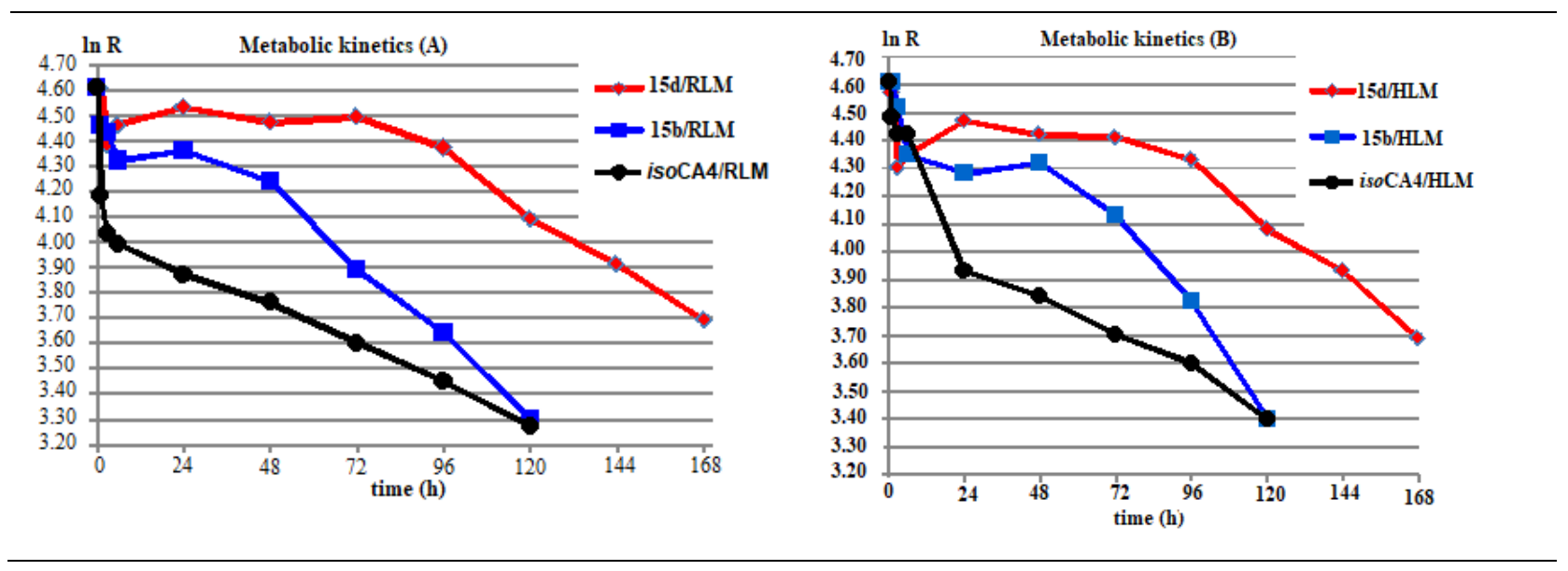

Figure 2. Metabolic stability profiles of isoCA-4, 15d and $\mathbf{1 5 b}$ derivatives in rat liver microsomes (A) and in human liver microsomes (B).

\subsubsection{Inhibition of tubulin polymerization for selected compounds}

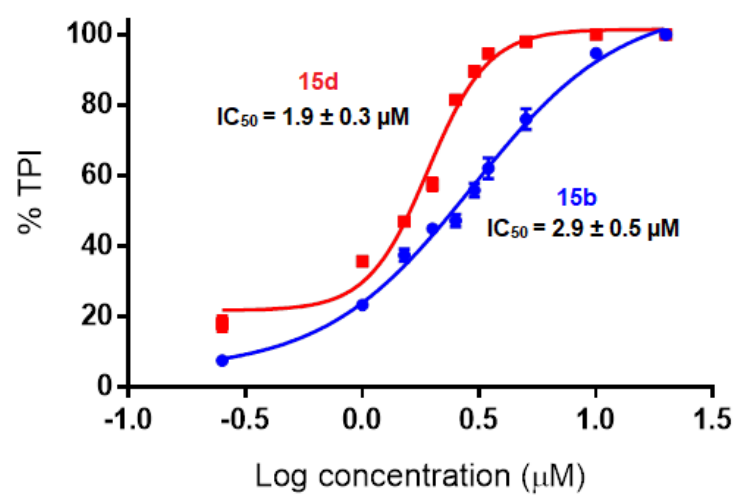

Figure 3. Effect of compounds $\mathbf{1 5 b}$ (blue line) and $\mathbf{1 5 d}$ (red line) on tubulin polymerization. Tubulin polymerization inhibition (TPI) is indicated in percentage. The polymerization percentage was calculated, for each concentration, by comparing the amplitude of tubulin-ligand curves from $4{ }^{\circ} \mathrm{C}$ to $37{ }^{\circ} \mathrm{C}$ with the amplitude observed for the negative control, considered as $100 \%$ of polymerization. Results are expressed as mean \pm SEM of three independent experiments. 
To investigate whether cytotoxic compounds $\mathbf{1 5 b}$ and $\mathbf{1 5 d}$ were exerting their activities by interacting with microtubules, their effects on in vitro polymerization of tubulin were examined using porcine brain tubulin, which was isolated following Shelanski's procedure.[41] As it can be seen in Figure 3, the selected compounds inhibited tubulin polymerization with micromolar $\mathrm{IC}_{50}$ values. It is of note that the concentrations required to inhibit tubulin polymerization using $\mathbf{1 5 b}$ and $\mathbf{1 5 d}\left(\mathrm{IC}_{50}\right.$ at a micromolar level) are much higher than those required for cytotoxicity and similar observations have been previously noticed in many other classes of antimitotic agents, including epithilones,[42] paclitaxel,[43] and isoCA-4 analogues prepared in our group.

\subsubsection{Cytotoxicity of 15d against eight other human cancer cells}

According to the metabolism and TPI results, we next decided to evaluate our lead compound 15d on eight other tumor cell lines: human glioblastoma (U87-MG), human lung epithelial (A549), human breast adenocarcinoma (MDAMB231), Human pancreatic carcinoma (MiaPACA2), Human lung cancer (HT1080), Chronic myeloid leukemia cells (K562), Doxorubicin-resistant chronic myeloid leukemia cells (K562R)[44] and Human colorectal adenocarcinoma cells (HT29). The results of this study are depicted in Table 3.

Table 3. Cytotoxicity against, U87-MG, A549, MDA-MB231, MiaPACA2, K562, K562R and HT29 human cancer cell lines.

\begin{tabular}{lcccccccc}
\hline \multicolumn{1}{c}{ Compounds } & U87-MG $^{b}$ & A549 $^{c}$ & MDA-MB231 $^{d}$ & MiaPACA2 $^{e}$ & HT1080 $^{f}$ & K562 $^{g}$ & K562R $^{h}$ & HT29 $^{i}$ \\
\hline $\mathrm{IC}_{50}{ }^{a}[\mathrm{nM}]$ 15d & $0.51 \pm 0.009$ & $0.70 \pm 0.02$ & $0.25 \pm 0.02$ & $0.09 \pm 0.005$ & $0.08 \pm 0.1$ & $0.26 \pm 0.03$ & $0.10 \pm 0.02$ & $0.84 \pm 0.14$ \\
$\mathrm{IC}_{50}[\mathrm{nM}]$ isoCA-4 & $8.24 \pm 0.9$ & $52.7 \pm 6.7$ & $1.98 \pm 0.6$ & $3.01 \pm 0.1$ & $0.91 \pm 0.07$ & $4.26 \pm 0.5$ & $5.13 \pm 0.04$ & $>100$ \\
\hline
\end{tabular}

${ }^{a} \mathrm{IC}_{50}$ is the concentration of $\mathbf{1 5 d}$ needed to reduce cell growth by $50 \%$ following $72 \mathrm{~h}$ cell treatment with the tested drug (average of three experiments). ${ }^{b}$ U87 Human glioblastoma cells. ${ }^{c}$ A549, Human lung epithelial cells. ${ }^{d}$ MDAMB231 Human breast adenocarcinoma cells. ${ }^{e}$ MiaPACA2 Human pancreatic carcinoma cells. ${ }^{f}$ HT1080 Human lung cancer cells. ${ }^{g}$ K562 Chronic myeloid leukemia cells. ${ }^{h}$ K562R Doxorubicin-resistant chronic myeloid leukemia cells. ${ }^{i}$ HT29 Human colorectal adenocarcinoma cells.

\subsubsection{Effect of $\mathbf{1 5 d}$ on cell cycle.}

Indole derivative 15d which displayed against all cancer cell lines a sub-nanomolar cytotoxicity level was next tested in dose-response experiments on K562 cell cycle distribution. K562 cells were treated for 24 h with increasing concentrations of $\mathbf{1 5 d}$ and DMSO was used as control. As seen in Fig. 4, 15d, at a concentration of $0.5 \mathrm{nM}$ has arrested

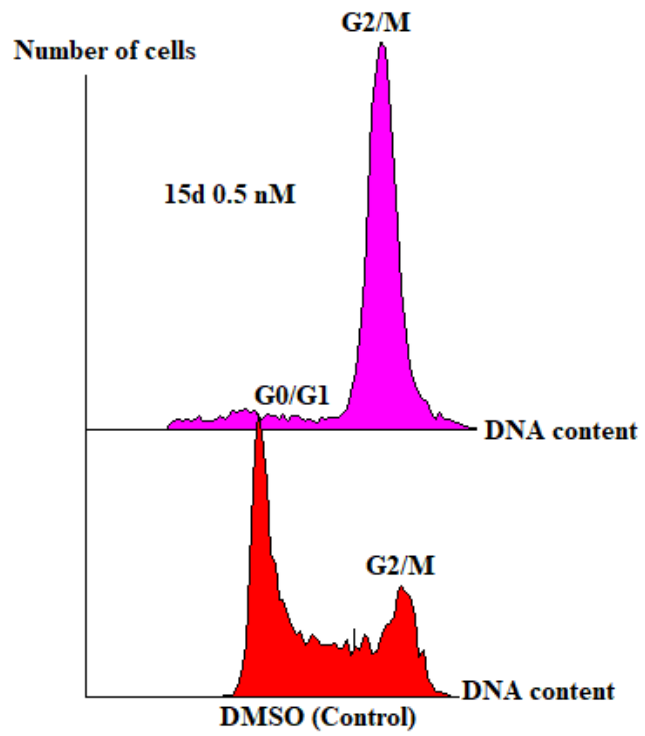

Figure 4. Effect of $\mathbf{1 5 d}$ on cell cycle distribution in K562 cells determined by flow cytometry analysis. DNA content was assessed via propidium iodide staining. 
the entire population of K562 cells in the G2/M phase of the cellular cycle. It is important to note that the cellular cycle blockade in the G2/M phase at such a low concentration has never been reported for isoCA-4 and analogues.

\subsubsection{Effects of 15d on mitochondrial dysfunction in K562 Cells}

Mitochondria play critical roles in cellular metabolism, homeostasis, and stress responses by generating ATP for energy and regulating cell death.[45] Mitochondrial dysfunction is usually caused by depolarization and is the early hallmark of toxicity mediated through caspase-induced apoptosis.[46] As shown in Figure 5, 15d induced mitochondrial dysfunction was detected using a fluorescence-based mitochondria-specific voltage-dependent dye, JC-1 assay. Thus, these results showed that 15d induced mitochondrial dysfunction in a concentration-dependent manner, with significant effects beginning at a very low concentration of $0.5 \mathrm{nM}$. Our study provides convincing evidence indicating that compound 15d dose-dependently caused caspase-induced apoptosis of K562 cells through mitochondrial dysfunction.
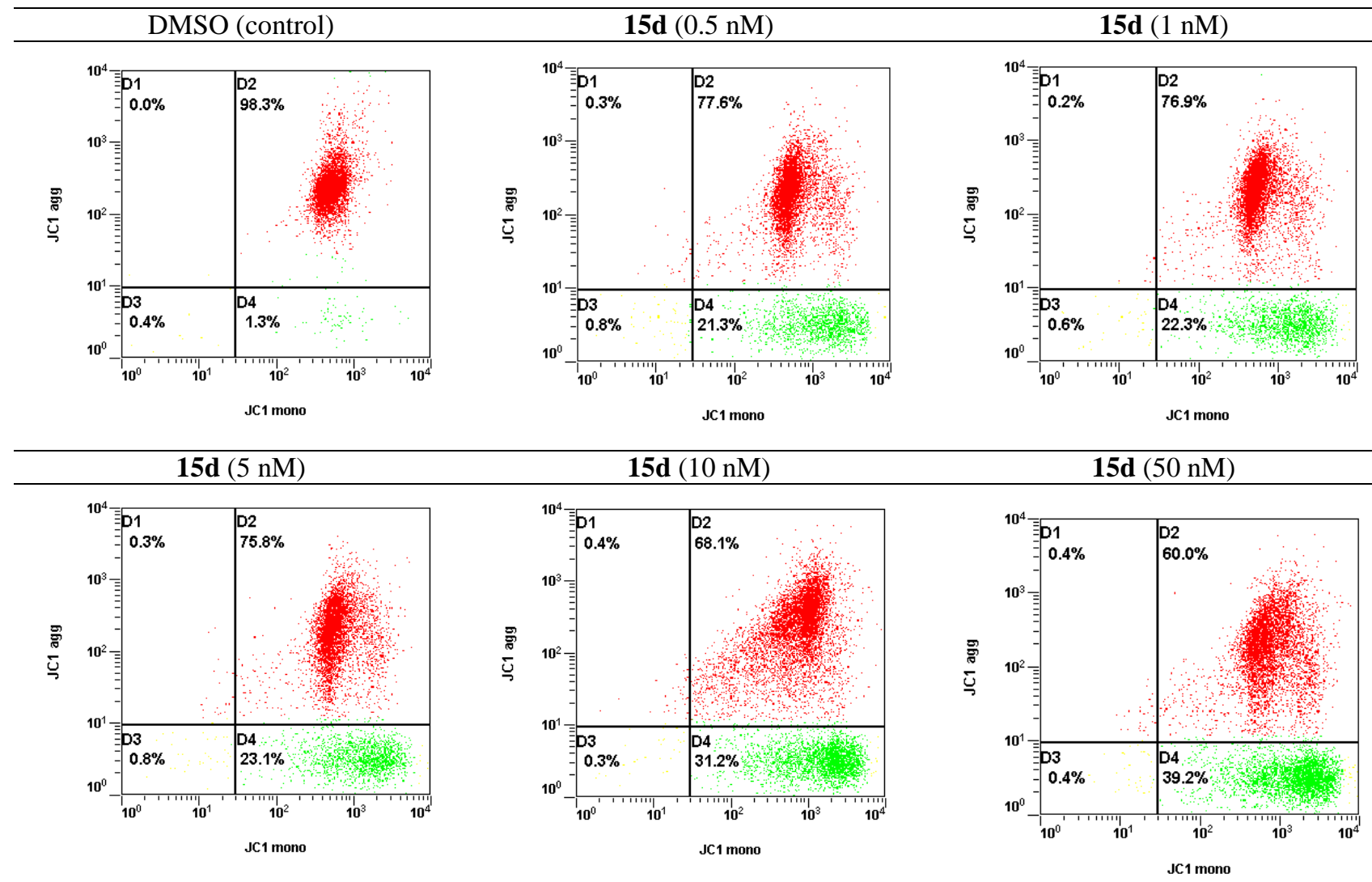

Figure 5 Compound 15d induced mitochondrial dysfunction in K562 leukemia cells. Cells were incubated with 15d at concentrations from 0.5 to $50 \mathrm{nM}$ for $48 \mathrm{~h}$ at $37{ }^{\circ} \mathrm{C}$. The portion of mitochondria dysfunction was measured using the JC1 assay.

\subsubsection{Inhibition of colony formation in K562 and imatinib-resistant K562 cells by $15 \boldsymbol{d}$}

We next quantified the inhibition of the clonogenic potential by $15 \mathbf{d}$ in a 3D culture environment using Methocult colony formation assays (CFA). 15d significantly reduced the number, total surface area and average size of K562 and imatinib resistant K562IR cell colonies (Figure 6).

(A) K562 cells

15d (nM)

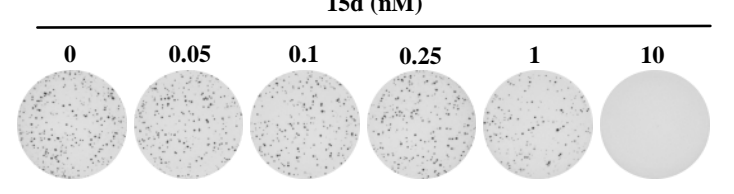

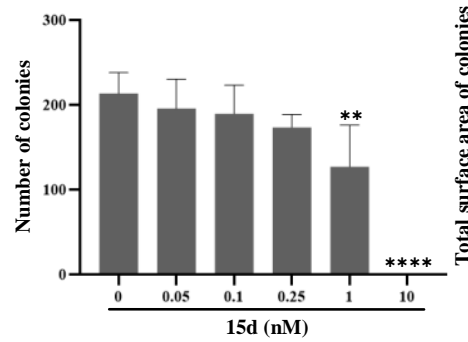

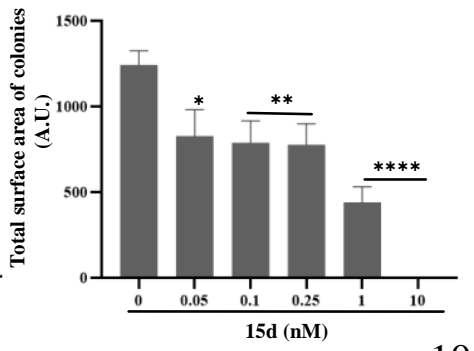



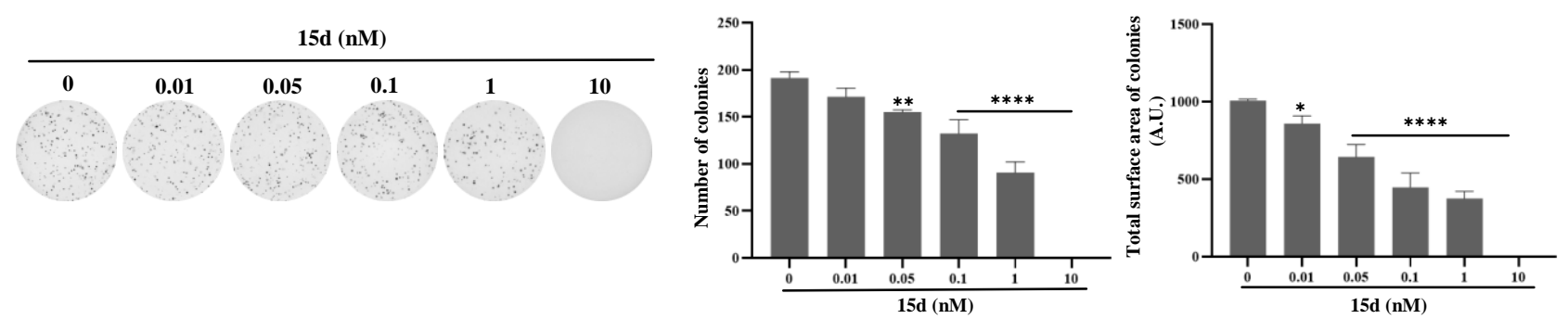

Figure 6. Representative pictures from three independent experiments of clonogenic assays after treatment with $\mathbf{1 5 d}$ (A) K562, (B) K562IR. Quantifications (number of colonies and the total surface area of colonies) are indicated. Statistical analysis was performed by two-way ANOVA, followed by Tukey's multiple comparisons test. Differences were considered significant when $* p<0.05$, $* * p<0.01, * * * p<0.001$ compared to control. $\mathrm{n} / \mathrm{s}$ : not significant.

\subsection{Molecular modelling}

Figure 7a presents the results of molecular docking calculations for compound $\mathbf{1 5 d}$ within the colchicine binding site of tubulin $\beta$ subunit (the structure obtained from X-ray crystal structure with accession code 6H9B).[30] The overall binding mode observed match that previously reported for isoCA-4 (see overlay on Figure 7b) and for compound $\mathbf{6 b},[28]$ where the quinazoline nucleus was accommodated in the lipophilic pocket ordinarily occupied by the trimethoxyphenyl A-ring. Interactions that can be expected given this binding mode hypothesis include notably (see Figure 6a) three potential hydrogen bonds between ( $i$ ) the side-chain SH group of the cysteine $\beta 241$ residue and the N1 atom of the quinazoline moiety (ii) the primary O-H function (hydrogen bond donor) of the indole with the carbonyl of backbone's asparagine $\beta 350$ (iii) the O-H (hydrogen bond acceptor) with the NH of backbone's valine $\beta 315$.

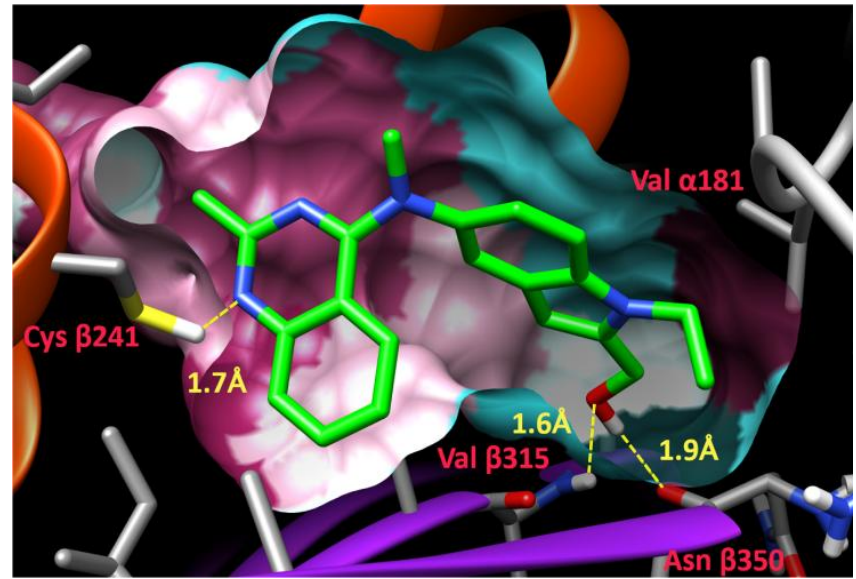

Figure 7a Putative binding mode of $\mathbf{1 5 d}$ (green) within colchicine binding site of tubulin X-ray structure (accession code 6H9B) showing expected hydrogen bonds between ligand atoms and cysteine $\beta 241$ and valine $\beta 315$.

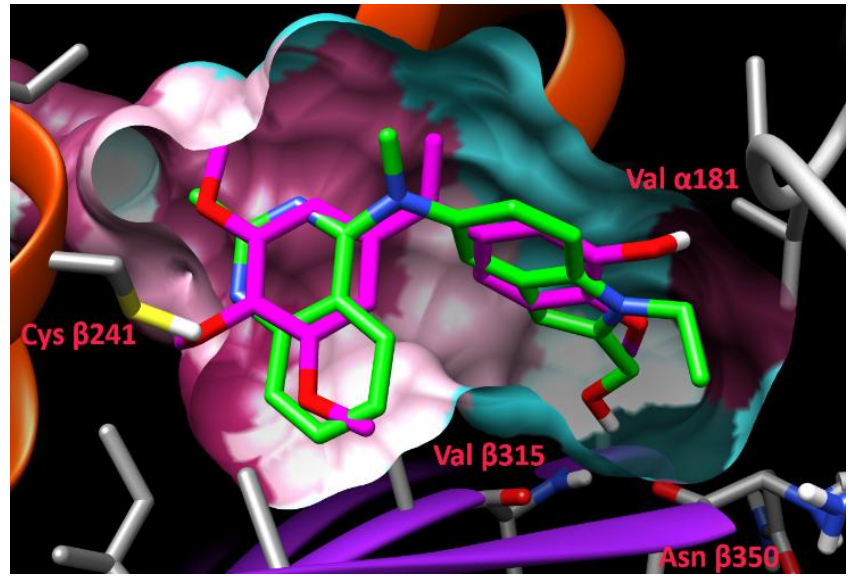

Figure 7b Docked pose of 15d (green) overlayed with isoCA-4 (fushia) in the tubulin binding site.

\section{Conclusion}

Overall, we have presented efficient syntheses of various original isoCA-4 analogues having as B-rings pyridoindoles, oxazinoindoles, and indoles nucleus. Among the 26 compounds synthesized, a large majority showed excellent cytotoxicity levels that can be compared to CA-4 and isoCA-4 as references. Compound 15d, which has a quinazoline as ring $\mathrm{A}$, a 2 -substituted indole as ring $\mathrm{B}$, and a $\mathrm{N}$-Methyl linker has proven to be the most promising compound of these different series. Indole-quinazoline compound 15d shows excellent cytotoxicity on 9 human cancer cell lines at a sub-nanomolar level that has never been observed in this research area. Moreover, it was observed that this compound 
presents a remarkable efficacy on K562R Doxorubicin-resistant chronic myeloid leukemia cell lines. This compound, which inhibits tubulin assembly into microtubules at a classic micromolar level, shows a very interesting metabolic stability, making it a promising drug candidate. Cell cycle studies have revealed that 15d blocks this cycle in the G2/M phase at a very low concentration of $0.5 \mathrm{nM}$, a concentration at which $\mathbf{1 5 d}$ also induced an important mitochondrial dysfunction. Interestingly, indole 15d was showed to significantly reduced the number, total surface area and average size of K562 and K562IR cell colonies in a dose-dependent manner. Finally, docking studies show that 15d adopts a similar orientation to that of isoCA-4 when bound to $\beta$-tubulin by establishing 3 stabilizing hydrogen bonds.

From a therapeutic point of view, it is important to note that compound $\mathbf{1 5 d}$ is certainly too cytotoxic to be used as in vivo. It is therefore appropriate to use this compound, due to its very high cytotoxicity $\left(\mathrm{IC}_{50}<<1 \mathrm{nM}\right)$ as a payload in an antibody-drug conjugate (ADC) strategy, as reported recently with CA-4.[47] Moreover, 15d could also be included in squalene nanoparticles, as shown in our lab with isoCA-4[48] for an improved efficacy, or in liposomal formulations. Further studies are currently underway in the lab to determine this compound's full potential for further development.

\section{Experimental}

\subsection{General considerations}

Solvent peaks were used as reference values, with $\mathrm{CDCl}_{3}$ at $7.26 \mathrm{ppm}$ for ${ }^{1} \mathrm{H} \mathrm{NMR}$ and 77.16 ppm for ${ }^{13} \mathrm{C}$ NMR, with $\left(\mathrm{CD}_{3}\right)_{2} \mathrm{CO}$ at $2.05 \mathrm{ppm}$ for ${ }^{1} \mathrm{H}$ NMR and $29.84 \mathrm{ppm}$ for ${ }^{13} \mathrm{C} \mathrm{NMR}$, and with DMSO- $\mathrm{d}_{6}$ at $2.50 \mathrm{ppm}$ for ${ }^{1} \mathrm{H}$ NMR and $39.5 \mathrm{ppm}$ for ${ }^{13} \mathrm{C}$ NMR. Chemical shifts $\delta$ are given in parts per million, and the following abbreviations are used: singlet (s), doublet (d), doublet of doublet (dd), triplet (t), td (triplet of doublet), ddd (doublet of doublet of doublet) multiplet (m) and broad singlet (bs). Reaction courses and product mixtures were routinely monitored by TLC on silica gel, and compounds were visualized with UV light $(254 \mathrm{~nm})$ or by solution of phosphomolybdic acid/ $\Delta$, anisaldehyde/ $\Delta$, ninhydrine/ $\Delta$ or vanillin/ $\Delta$. Flash chromatography was performed using silica gel 60 (40-63 mm, 230-400 mesh) at medium pressure (200 mbar). Fluorobenzene was used as received, and dioxane, dichloromethane, cyclohexane, and tetrahydrofuran were classically dried. Organic extracts were, in general, dried over $\mathrm{MgSO}_{4}$ or $\mathrm{Na}_{2} \mathrm{SO}_{4}$. High-resolution mass spectra were recorded on a Bruker Daltonics micrOTOF-Q II instrument. All products reported showed ${ }^{1} \mathrm{H}$ and ${ }^{13} \mathrm{C}$ NMR spectra in agreement with the assigned structures. LCMS were done with H2O/ACN/0.1\%Formic Acid gradient 1-30\% 15 min with column Sunfire C18 - 2.1x150mm - 3.5 $\mu \mathrm{m}$. IR spectra were measured on a Brucker Vector 22 spectrophotometer (neat, $\mathrm{cm}^{-1}$ ).

\subsection{Procedure for the synthesis of new compounds}

4.2.1 General procedure for the Barluenga coupling reaction (protocol A) if necessary followed by a desilylation reaction used for: 10a, 10d, 12a, 12b, 15a, 15b, 15f, 15g and $15 \mathrm{l}$.

A sealed tube under argon atmosphere was charged at room temperature with 1 eq of appropriate 5-bromo-indole derivative $(0.2 \mathrm{mmol})(\mathbf{9}, \mathbf{1 3}, \mathbf{1 4 b}, \mathbf{1 4 c}$ and $\mathbf{1 4 d}), 1.2 \mathrm{eq}$ of corresponding $N$-tosylhydrazone $(0.24 \mathrm{mmol})$, $\mathrm{Pd}_{2} \mathrm{dba}_{3} . \mathrm{CHCl}_{3}(5 \mathrm{~mol} \%)$, XPhos $(10 \mathrm{~mol} \%)$ and $2.4 \mathrm{eq}$ of $\mathrm{LiO} t \mathrm{Bu}(0.5 \mathrm{mmol})$ in dry dioxane. The mixture was then heated at $100{ }^{\circ} \mathrm{C}$ until disappearance of bromo indole derivative evaluated by silica TLC ( $8 / 2$ cyclohexane/AcOEt). The crude mixture was then allowed to room temperature, filtered through Celite pad with ethyl acetate, and the solvents were evaporated under reduced pressure and the crude residue was purified by silica gel chromatography (95/5 to 85/15 of cyclohexane/EtOAc). The crude was then concentrated under vacuum to give a solid (10a, 10d, 12a, 12b). For compounds having a O-Si group, the crude residue was dissolved in dry THF with 1.1 eq of TBAF (1M in THF) for $3 \mathrm{~h}$ at room temperature. Reaction completion was evaluated by silica TLC (6/4 cyclohexane/AcOEt). After completion, the solvent is evaporated under reduced pressure and the crude residue was purified by silica gel chromatography (90/10 to 70/30 of cyclohexane/EtOAc) to give the product as a solid (15a, 15b, 15f, $\mathbf{1 5 g}$ and $\mathbf{1 5 l})$. 
4.2.2. General procedure for the Buchwald-Hartwig coupling reaction (protocol B) followed by a N-methylation reaction for 10b, 10c, 11c, 12c, 12d, 12e, 12f, 12g, 15i, 15j and 15k and, for 15c, 15d, 15e and 15h a N-methylation reaction and a desilylation step.

A sealed tube under argon atmosphere was charged at room temperature with 1 eq of corresponding 5-bromo-indole derivative $(0.2 \mathrm{mmol})(\mathbf{9}, \mathbf{1 3}, \mathbf{1 4 b}, \mathbf{1 4 c}, \mathbf{1 4 d}, \mathbf{1 4 \mathbf { e }}), 1.2$ eq of appropriate primary amine $(0.24 \mathrm{mmol}), \mathrm{Pd}_{2} \mathrm{dba}_{3} . \mathrm{CHCl}_{3}(5$ mol\%), XPhos $(10 \mathrm{~mol} \%)$ and $1.5 \mathrm{eq}(0.3 \mathrm{mmol})$ of $\mathrm{NaO} t \mathrm{Bu}\left(\right.$ or $\mathrm{Cs}_{2} \mathrm{CO}_{3}$ for $\left.12 \mathrm{e}\right)$ in dry dioxane. The mixture was then heated at $100{ }^{\circ} \mathrm{C}$ until disappearance of bromo indole derivative evaluated by silica TLC (7/3 cyclohexane/AcOEt). The crude mixture was then allowed to cool down to room temperature, filtration through Celite, and the solvents were evaporated under reduced pressure. The crude residue was dissolved in freshly distilled DMF $(4 \mathrm{~mL})$ at $0{ }^{\circ} \mathrm{C}$ and 2 eq of $\mathrm{NaH}$ were added. After 20 min., 1.2 eq of MeI was slowly added and the mixture was stirred at room temperature for 6 h. Reaction completion was evaluated by silica TLC (6/4 cyclohexane/EtOAc). The reaction was cooled to $0{ }^{\circ} \mathrm{C}$, saturated aqueous $\mathrm{NH}_{4} \mathrm{Cl}$ solution was added by small portions and the mixture was extracted with EtOAc. The organic layer was washed with saturated aqueous $\mathrm{NH}_{4} \mathrm{Cl}$ solution $(2 \mathrm{x})$, saturated aqueous $\mathrm{NaHCO}_{3}$ solution and brine. The combined organic layers were dried over $\mathrm{MgSO}_{4}$ and concentrated in vacuum. The crude product was purified by silica gel chromatography (95/5 to 80/20 cyclohexane/EtOAc). The product was then concentrated under vacuum to give a solid (10b, 10c, 12c, 12d, 12e, 12f, 12g, 15i, 15j and 15k). For compounds having a OTBS group, the crude residue was dissolved in dry THF with 1.1 eq of TBAF (1M in THF) at room temperature until disappearance of starting materiel evaluated by silica TLC (6/4 cyclohexane/AcOEt). After completion the solvent was evaporated under reduced pressure and the crude residue was purified by silica gel chromatography (90/10 to 60/40 of cyclohexane/EtOAc) to give the product as a solid $(\mathbf{1 5 c}, \mathbf{1 5 d}, \mathbf{1 5 e}$ and $\mathbf{1 5 h})$.

\subsubsection{General aromatization procedure leading to 11 a-c (protocol C).}

A sealed tube under argon atmosphere was charged at room temperature with 1 eq of corresponding dihydropyrido indole 10a or $10 \mathrm{~b}$ and $\mathrm{Pd} / \mathrm{C}(20 \mathrm{~mol} \%)$ in $p$-xylene. The mixture was then heated at $145{ }^{\circ} \mathrm{C}$ for $48 \mathrm{~h}$. Reaction completion was evaluated by analytical HPLC. The crude mixture was then allowed to cool down to room temperature, Filtration through Celite, and the solvent was evaporated under reduced pressure. The crude product was purified by inverse phase column on preparative HPLC. The product was then concentrated under vacuum to give compounds 11a or 11b. Compound 11c was obtained after a Buchwald-Hartwig coupling reaction (protocol B) between 9 and 4aminoquinazoline followed by a $N$-methylation reaction and an oxidation step (as for 11a,b; protocol C).

\subsubsection{Description of new compounds}

\subsubsection{2-(1-(3,4,5-Trimethoxyphenyl)vinyl)-6,9-dihydropyrido[1,2-a]indole 10a}

Protocol A. Column chromatography on silica gel afforded $87 \mathrm{mg}$ of the product as light brown solid $(0.24 \mathrm{mmol}$, yield $60 \%) ; \mathrm{TLC}\left(\mathrm{SiO}_{2}, 8 / 2\right.$ cyclohexane/EtOAc); $\mathrm{R}_{\mathrm{f}}=0.69 ; \mathrm{m} . \mathrm{p} .=89{ }^{\circ} \mathrm{C}{ }^{1} \mathrm{H}$ NMR $(300 \mathrm{MHz}$, Acetone-d $\left.)\right) \delta 7.49(\mathrm{~d}, J=1.0$ $\mathrm{Hz}, 1 \mathrm{H}), 7.30(\mathrm{dt}, J=8.5,0.8 \mathrm{~Hz}, 1 \mathrm{H}), 7.13(\mathrm{dd}, J=8.5,1.7 \mathrm{~Hz}, 1 \mathrm{H}), 6.66(\mathrm{~s}, 2 \mathrm{H}), 6.25(\mathrm{~d}, J=1.0 \mathrm{~Hz}, 1 \mathrm{H}), 6.09(\mathrm{~d}, \mathrm{~J}=$ $1.2 \mathrm{~Hz}, 2 \mathrm{H}), 5.38(\mathrm{q}, J=1.6 \mathrm{~Hz}, 2 \mathrm{H}), 4.75-4.56(\mathrm{~m}, 2 \mathrm{H}), 3.77(\mathrm{~s}, 3 \mathrm{H}), 3.75(\mathrm{~s}, 6 \mathrm{H}), 3.60(\mathrm{dtd}, J=6.2,4.6,3.9,2.4 \mathrm{~Hz}$, $2 \mathrm{H}) ;{ }^{13} \mathrm{C}$ NMR (75 MHz, Acetone-d 6 ) $\delta 154.0$ (2C), 152.5, 139.2, 139.1, 136.5, 134.8, 134.0, 129.2, 122.8, 121.7, 121.5 , 120.2, 112.3, 109.3, 107.0 (2C), 98.3, 60.6, 56.4 (2C), 42.5, 24.5; IR neat $\left(\mathrm{cm}^{-1}\right): 2934,1579,1504,1412,1343,1235$, 1125, 1005; HRMS $\left(\mathrm{ESI}^{+}\right.$) for $\mathrm{C}_{23} \mathrm{H}_{24} \mathrm{NO}_{3}[\mathrm{M}+\mathrm{H}]^{+}$: calcd 362.1756 found 362.1753 .

\subsubsection{N-Methyl-N-(2-methylquinolin-4-yl)-6,9-dihydropyrido[1,2-a]indol-2-amine 10b}

Protocol B followed by a $N$-Methylation reaction. Column chromatography on silica gel afforded 46 mg of the product as yellow solid (0.13 mmol, yield 71\%); $\mathrm{TLC}\left(\mathrm{SiO}_{2}, 9 / 1 \mathrm{DCM} / \mathrm{MeOH}\right) ; \mathrm{R}_{\mathrm{f}}=0.58 ; \mathrm{m} . \mathrm{p}=84{ }^{\circ} \mathrm{C} ;{ }^{1} \mathrm{H} \mathrm{NMR}(300 \mathrm{MHz}$, $\left.\mathrm{CDCl}_{3}\right) \delta 7.94(\mathrm{~d}, J=8.4 \mathrm{~Hz}, 1 \mathrm{H}), 7.58(\mathrm{t}, J=7.4 \mathrm{~Hz}, 1 \mathrm{H}), 7.52-7.40(\mathrm{~m}, 1 \mathrm{H}), 7.28-7.18(\mathrm{~m}, 1 \mathrm{H}), 7.18-7.10(\mathrm{~m}$, 
1H), $7.02(\mathrm{dd}, J=8.5,6.8 \mathrm{~Hz}, 1 \mathrm{H}), 6.94-6.82(\mathrm{~m}, 2 \mathrm{H}), 6.20(\mathrm{~d}, J=15.9 \mathrm{~Hz}, 1 \mathrm{H}), 6.04(\mathrm{~s}, 1 \mathrm{H}), 6.00-5.87(\mathrm{~m}, 1 \mathrm{H})$, $4.59(\mathrm{dd}, J=5.6,3.5 \mathrm{~Hz}, 2 \mathrm{H}), 3.71-3.51(\mathrm{~m}, 2 \mathrm{H}), 3.49(\mathrm{~s}, 3 \mathrm{H}), 2.72(\mathrm{~s}, 3 \mathrm{H}) ;{ }^{13} \mathrm{C} \mathrm{NMR}\left(75 \mathrm{MHz}\right.$, Acetone-d $\left._{6}\right) \delta 164.2$, 158.2, 156.5, 146.9, 144.2, 135.8, 130.4, 126.8, 126.5, 124.8, 122.7, 121.4, 119.9, 118.4, 115.9, 111.1, 109.2, 100.1, 98.3, 45.3, 42.5, 24.5, 23.4; IR $\left(\mathrm{cm}^{-1}\right): 2932,2920,1486,1466,1362,1212,1088,805,787$; HRMS $\left(\mathrm{ESI}^{+}\right)$for $\mathrm{C}_{23} \mathrm{H}_{22} \mathrm{~N}_{3}[\mathrm{M}+\mathrm{H}]^{+}$: calcd 340.1808 found 340.1805 .

\subsubsection{N-Methyl-N-(3,4,5-trimethoxyphenyl)-6,9-dihydropyrido[1,2-a]indol-2-amine 10c}

Protocol B followed by a $N$-Methylation reaction. Column chromatography on silica gel afforded 58 mg of the product as a yellow oil (0.16 mmol, yield $57 \%)$; TLC $\left(\mathrm{SiO}_{2}, 7 / 3\right.$ cyclohexane/EtOAc); ${ }^{1} \mathrm{H}$ NMR (300 MHz, Acetone-d $\left.)\right) \delta .35$ $-7.27(\mathrm{~m}, 2 \mathrm{H}), 6.97(\mathrm{dd}, J=8.6,2.2 \mathrm{~Hz}, 1 \mathrm{H}), 6.61$ (dt, $J=9.9,1.9 \mathrm{~Hz}, 1 \mathrm{H}), 6.31(\mathrm{~s}, 1 \mathrm{H}), 6.12-5.99$ (m, $3 \mathrm{H}), 4.13(\mathrm{t}, J$ $=7.1 \mathrm{~Hz}, 2 \mathrm{H}), 3.67(\mathrm{~s}, 6 \mathrm{H}), 3.64(\mathrm{~s}, 3 \mathrm{H}), 3.28(\mathrm{~s}, 3 \mathrm{H}), 2.66(\mathrm{tdd}, J=6.9,4.4,1.9 \mathrm{~Hz}, 2 \mathrm{H}){ }^{13} \mathrm{C}$ NMR $(75 \mathrm{MHz}$, Acetone$\left.\mathrm{d}_{6}\right) \delta 154.6(2 \mathrm{C}), 148.2,142.9,136.5,135.6,132.2,130.5,125.6,121.4,120.8,117.5,110.4,100.0$ (2C), 95.2, 60.7, 56.3 (2C), 41.6, 40.4, 24.9; IR ( $\left.\mathrm{cm}^{-1}\right): 3001,2955,2254,1655,1504,1412,1235,1125,1005,797$; HRMS $\left(\mathrm{ESI}^{+}\right)$for $\mathrm{C}_{22} \mathrm{H}_{25} \mathrm{~N}_{2} \mathrm{O}_{3}[\mathrm{M}+\mathrm{H}]^{+}$: calcd 365.1865 found 365.1858 .

\subsubsection{2-(1-(2-Methylquinolin-4-yl)vinyl)-6,9-dihydropyrido[1,2-a]indole 10d}

Protocol A. Column chromatography on silica gel afforded $71 \mathrm{mg}$ of the product as a light brown solid $(0.21 \mathrm{mmol}$, yield 53\%); TLC $\left(\mathrm{SiO}_{2}, 6 / 4\right.$ cyclohexane/EtOAc); $\mathrm{R}_{\mathrm{f}}=0.66 ;$ m.p. $=129{ }^{\circ} \mathrm{C}{ }^{1} \mathrm{H} \mathrm{NMR}\left(300 \mathrm{MHz}, \mathrm{Methanol}-\mathrm{d}_{4}\right) \delta 7.95$ $(\mathrm{d}, \mathrm{J}=8.5 \mathrm{~Hz}, 1 \mathrm{H}), 7.72(\mathrm{~d}, J=8.4 \mathrm{~Hz}, 1 \mathrm{H}), 7.60(\mathrm{ddd}, J=8.4,6.8,1.5 \mathrm{~Hz}, 1 \mathrm{H}), 7.34(\mathrm{~s}, 1 \mathrm{H}), 7.27(\mathrm{~d}, J=1.6 \mathrm{~Hz}, 1 \mathrm{H})$, $7.24(\mathrm{dd}, J=8.4,1.4 \mathrm{~Hz}, 1 \mathrm{H}), 7.17(\mathrm{~d}, J=8.6 \mathrm{~Hz}, 1 \mathrm{H}), 7.09(\mathrm{dd}, J=8.6,1.8 \mathrm{~Hz}, 1 \mathrm{H}), 6.06(\mathrm{~s}, 1 \mathrm{H}), 6.00(\mathrm{~s}, 2 \mathrm{H}), 5.95$ $(\mathrm{d}, J=1.3 \mathrm{~Hz}, 1 \mathrm{H}), 5.27(\mathrm{~d}, J=1.3 \mathrm{~Hz}, 1 \mathrm{H}), 4.54-4.42(\mathrm{~m}, 2 \mathrm{H}), 3.54-3.43(\mathrm{~m}, 2 \mathrm{H}), 2.72(\mathrm{~s}, 3 \mathrm{H}) ;{ }^{13} \mathrm{C} \mathrm{NMR}(75 \mathrm{MHz}$, Methanol- $\left.\mathrm{d}_{4}\right) \delta 160.2,152.3,149.1,148.8,137.0,135.5,133.1,130.7,129.9,128.5,127.6,127.0,126.8,123.8,123.1$, 121.5, 120.1, 119.2, 115.1, 109.9, 98.6, 42.7, 24.71, 24.65; IR $\left(\mathrm{cm}^{-1}\right): 3044,2924,1592,1485,1463,1446,1393,1366$, 882, 767; HRMS $\left(\mathrm{ESI}^{+}\right.$) for $\mathrm{C}_{24} \mathrm{H}_{21} \mathrm{~N}_{2}[\mathrm{M}+\mathrm{H}]^{+}$: calcd 337.1705 found 337.1700 .

\subsubsection{2-(1-(3,4,5-Trimethoxyphenyl) vinyl)pyrido[1,2-a]indole 11a}

Protocol C. A sealed tube under argon atmosphere was charged at room temperature with 1 eq of $10 a$ and $\mathrm{Pd} / \mathrm{C}(20$ mol\%) in $p$-xylene. The mixture was then heated at $145^{\circ} \mathrm{C}$ for $48 \mathrm{~h}$. Reaction completion was evaluated by analytical HPLC. The crude mixture was then allowed to cool down to room temperature, filtration through Celite, and the solvent was evaporated under reduced pressure. The crude product was purified by inverse phase column on preparative HPLC to give compound $11 \mathrm{mg}$ 11a as brown oil (0.03 mmol, yield 37\%); TLC $\left(\mathrm{SiO}_{2}, 8 / 2\right.$ Cyclohexane/EtOAc $) ; \mathrm{R}_{\mathrm{f}}=0.70 ;{ }^{1} \mathrm{H}$ $\operatorname{NMR}\left(300 \mathrm{MHz}\right.$, Acetone-d $\left._{6}\right) \delta 8.67(\mathrm{~d}, J=7.2 \mathrm{~Hz}, 1 \mathrm{H}), 8.08(\mathrm{~d}, J=8.7 \mathrm{~Hz}, 1 \mathrm{H}), 7.74(\mathrm{~d}, J=1.7 \mathrm{~Hz}, 1 \mathrm{H}), 7.51(\mathrm{dt}, J=$ 9.3, 1.2 Hz, 1H), 7.27 (dd, $J=8.7,1.7 \mathrm{~Hz}, 1 \mathrm{H}), 6.96$ (ddd, $J=9.2,6.3,1.1 \mathrm{~Hz}, 1 \mathrm{H}), 6.66(\mathrm{~s}, 2 \mathrm{H}), 6.58$ (ddd, $J=7.3$, 6.3, $1.2 \mathrm{~Hz}, 2 \mathrm{H}), 5.48(\mathrm{~s}, 2 \mathrm{H}), 3.77$ (s, 3H), $3.76(\mathrm{~s}, 6 \mathrm{H}) ;{ }^{13} \mathrm{C}$ NMR (75 MHz, Acetone) $\delta$ 154.1 (2C), 152.1, 143.2, 139.2, 138.7, 137.8, 137.0, 125.7, 123.1 (2C), 121.1, 120.8, 119.9, 113.6, 111.2, 108.8, 106.9 (2C), 92.4, 60.6, 56.4 (2C); IR $\left(\mathrm{cm}^{-1}\right): 2928,1587,1500,1412,1343,1235,1125,1005,807 . \mathrm{HRMS}\left(\mathrm{ESI}^{+}\right)$for $\mathrm{C}_{23} \mathrm{H}_{22} \mathrm{NO}_{3}[\mathrm{M}+\mathrm{H}]^{+}: \mathrm{calcd}$ 360.1600 found 360.1613

\subsubsection{N-Methyl-N-(2-methylquinolin-4-yl)pyrido[1,2-a]indol-2-amine $\mathbf{1 1 b}$}

Protocol C. A sealed tube under argon atmosphere was charged at room temperature with 1 eq of $\mathbf{1 0 b}$ and $\mathrm{Pd} / \mathrm{C}(20$ mol\%) in $p$-xylene. The mixture was then heated at $145^{\circ} \mathrm{C}$ for $48 \mathrm{~h}$. Reaction completion was evaluated by analytical HPLC. The crude mixture was then allowed to cool down to room temperature, filtration through Celite, and the solvent was evaporated under reduced pressure. The crude product was purified by inverse phase column on preparative HPLC to give compounds $8 \mathrm{mg}$ of $\mathbf{1 1 b}$ as a brown solid (0.02 mmol, yield 32\%); TLC $\left(\mathrm{SiO}_{2}, 9 / 1 \mathrm{DCM} / \mathrm{MeOH}\right) ; \mathrm{R}_{\mathrm{f}}=0.65$; m.p. $=103{ }^{\circ} \mathrm{C} ;{ }^{1} \mathrm{H}$ NMR $(300 \mathrm{MHz}$, Methanol-d 4$) \delta 8.66-8.45(\mathrm{~m}, 2 \mathrm{H}), 8.12(\mathrm{~d}, J=9.0 \mathrm{~Hz}, 1 \mathrm{H}), 7.78(\mathrm{~d}, J=8.4 \mathrm{~Hz}$, 
1H), $7.66-7.52(\mathrm{~m}, 2 \mathrm{H}), 7.45(\mathrm{~d}, J=9.3 \mathrm{~Hz}, 1 \mathrm{H}), 7.24(\mathrm{~d}, J=8.6 \mathrm{~Hz}, 1 \mathrm{H}), 7.18-7.13(\mathrm{~m}, 1 \mathrm{H}), 7.12(\mathrm{~s}, 1 \mathrm{H}), 7.01(\mathrm{~d}, J$ $=7.8 \mathrm{~Hz}, 1 \mathrm{H}), 6.96(\mathrm{~d}, J=9.5 \mathrm{~Hz}, 1 \mathrm{H}), 6.58(\mathrm{t}, J=6.5 \mathrm{~Hz}, 1 \mathrm{H}), 3.75(\mathrm{~s}, 3 \mathrm{H}), 2.78(\mathrm{~s}, 3 \mathrm{H}) ;{ }^{13} \mathrm{C}$ NMR $(75 \mathrm{MHz}$, Acetone- $\left.\mathrm{d}_{6}\right) \delta 164.0,159.3,155.8,148.8,147.1,129.9,128.2,126.2,125.7,124.9,123.3,122.3,119.6,117.1,116.2$, 115.2, 113.9, 112.8, 111.8, 108.8, 92.2, 44.3, 24.4; IR ( $\left.\mathrm{cm}^{-1}\right):$ 2960, 2926, 1563, 1506, 1466, 1344, 1261, 1096, 800; HRMS $\left(\mathrm{ESI}^{+}\right.$) for $\mathrm{C}_{23} \mathrm{H}_{20} \mathrm{~N}_{3}[\mathrm{M}+\mathrm{H}]^{+}$: calcd 338.1652 found 338.1693 .

\subsubsection{N-Methyl-N-(2-methylquinazolin-4-yl)pyrido[1,2-a]indol-2-amine 11c}

Protocol A followed by a $N$-methylation reaction and an oxidation step (Protocol C). A sealed tube under argon atmosphere was charged at room temperature with 1 eq of corresponding $\mathbf{9}, 1.2$ eq of 2-methylquinazolin-4-amine $(0.24$ $\mathrm{mmol}), \mathrm{Pd}_{2} \mathrm{dba}_{3} \cdot \mathrm{CHCl}_{3}(5 \mathrm{~mol} \%)$, XPhos $(10 \mathrm{~mol} \%)$ and 1.5 eqs $(0.3 \mathrm{mmol})$ of $\mathrm{NaO} t \mathrm{Bu}$ in dry dioxane. The mixture was then heated at $100{ }^{\circ} \mathrm{C}$ for $1 \mathrm{~h}$. The crude mixture was then allowed to cool down to room temperature, filtration through Celite with ethyl acetate, and the solvents were evaporated under reduced pressure. The crude residue was dissolved in freshly distilled DMF $(4 \mathrm{~mL})$ at $0{ }^{\circ} \mathrm{C}$ and 2 eq of $\mathrm{NaH}$ were added. After $20 \mathrm{~min}$., 1.2 eq of MeI was slowly added and the mixture was stirred at room temperature for $3 \mathrm{~h}$. Reaction completion was evaluated by silica TLC (9/1 $\mathrm{DCM} / \mathrm{MeOH}$ ). The reaction was cooled to $0^{\circ} \mathrm{C}$, saturated aqueous $\mathrm{NH}_{4} \mathrm{Cl}$ solution was added by small portions and the mixture was extracted with EtOAc. The organic layer was washed with saturated aqueous $\mathrm{NH}_{4} \mathrm{Cl}$ solution (2x), saturated aqueous $\mathrm{NaHCO}_{3}$ solution (1x) and brine (2x). The combined organic layers were dried over $\mathrm{MgSO}_{4}$ and concentrated in vacuum. The crude was charged under argon at room temperature with $\mathrm{Pd} / \mathrm{C}(20 \mathrm{~mol} \%)$ in $p$-xylene. The mixture was then heated at $145^{\circ} \mathrm{C}$ for $72 \mathrm{~h}$. Reaction completion was evaluated by analytical HPLC. The crude mixture was then allowed to cool down to room temperature, filtration through a silica pad, and the solvent was evaporated under reduced pressure. The crude product was purified by inverse phase column on preparative to give $10 \mathrm{mg}$ of the product as red oil $\left(0.03 \mathrm{mmol}\right.$, yield 50\%); TLC $\left(\mathrm{SiO}_{2}, 95 / 5 \mathrm{DCM} / \mathrm{MeOH}\right) ; \mathrm{R}_{\mathrm{f}}=0.70 ;{ }^{1} \mathrm{H} \mathrm{NMR}(200 \mathrm{MHz}$, $\left.\mathrm{CDCl}_{3}\right) \delta 8.31(\mathrm{~d}, J=6.7 \mathrm{~Hz}, 1 \mathrm{H}), 7.88(\mathrm{~d}, J=8.9 \mathrm{~Hz}, 1 \mathrm{H}), 7.77(\mathrm{~d}, J=7.9 \mathrm{~Hz}, 1 \mathrm{H}), 7.62(\mathrm{~s}, 1 \mathrm{H}), 7.47(\mathrm{t}, J=9.1 \mathrm{~Hz}$, 2H), $7.09(\mathrm{~d}, J=8.5 \mathrm{~Hz}, 1 \mathrm{H}), 7.02-6.86(\mathrm{~m}, 2 \mathrm{H}), 6.82(\mathrm{~d}, J=7.0 \mathrm{~Hz}, 1 \mathrm{H}), 6.58(\mathrm{~d}, J=4.8 \mathrm{~Hz}, 1 \mathrm{H}), 6.52(\mathrm{~d}, J=6.4$ $\mathrm{Hz}, 1 \mathrm{H}), 3.74$ (s, 3H), 2.77 (s, 3H).; ${ }^{13} \mathrm{C}$ NMR (101 MHz, DMSO) $\delta 162.4,161.3,151.7,143.4,137.1,131.7,129.2$, 127.4, 125.8, 125.6, 123.8, 123.0, 121.1, 118.7, 117.8, 116.6, 114.4, 113.0, 108.3, 91.4, 42.8, 26.1; IR $\left(\mathrm{cm}^{-1}\right): 3418$, 3049, 2254, 1659, 1341, 1023, 1001, 890; HRMS (ESI ${ }^{+}$) for $\mathrm{C}_{22} \mathrm{H}_{19} \mathrm{~N}_{4}[\mathrm{M}+\mathrm{H}]^{+}$: calcd 339.1610 found 339.1613 .

\subsubsection{Synthesis of 8-bromo-3,4-dihydro-1H-[1,4]oxazino[4,3-a]indole $\mathbf{1 3}$}

1 eq $(20 \mathrm{mg})$ of commercially available (5-bromo-1H-indol-2-yl)methanol 14a was charged in a $25 \mathrm{~mL}$ round bottom flask, dissolved with $7 \mathrm{~mL}$ of fluorobenzene and cooled to $0{ }^{\circ} \mathrm{C}$. Then, $3 \mathrm{eq}(11 \mathrm{mg})$ of $\mathrm{NaH}$ (60\% dispersion in mineral oil) were slowly added to the solution. After $10 \mathrm{~min}$. of stirring, the vinyl sulfonium salt was slowly injected to the solution. The reaction was next stirred at room temperature for $30 \mathrm{~min}$. Evaporation of flurobenzene gave a crude product which was purified by silica gel chromatography ( $95 / 5$ to $85 / 15$ cyclohexane/EtOAc). The product was then concentrated under vacuum to give $20.4 \mathrm{mg}$ of $\mathbf{1 3}$ (91\%) as a white solid.

\subsubsection{8-(1-(2-Methylquinolin-4-yl)vinyl)-3,4-dihydro-1H-[1,4]oxazino[4,3-a]indole 12a}

Protocol A. Column chromatography on silica gel afforded $50 \mathrm{mg}$ of the product as a white-off solid $(0.15 \mathrm{mmol}$, yield 82\%); TLC $\left(\mathrm{SiO}_{2}, 8 / 2\right.$ Cyclohexane/AcOEt $) ; \mathrm{R}_{\mathrm{f}}=0.66 ; \mathrm{m} . \mathrm{p}=191{ }^{\circ} \mathrm{C} ;{ }^{1} \mathrm{H}$ NMR $\left(300 \mathrm{MHz}\right.$, Acetone- $\left.d_{6}\right) \delta 7.97(\mathrm{~d}, J=$ $8.5 \mathrm{~Hz}, 1 \mathrm{H}), 7.70(\mathrm{dd}, J=8.4,1.4 \mathrm{~Hz}, 1 \mathrm{H}), 7.61(\mathrm{ddd}, J=8.4,6.8,1.5 \mathrm{~Hz}, 1 \mathrm{H}), 7.36(\mathrm{~d}, J=1.7 \mathrm{~Hz}, 1 \mathrm{H}), 7.34(\mathrm{~s}, 1 \mathrm{H})$, $7.36-7.23(\mathrm{~m}, 2 \mathrm{H}), 7.20(\mathrm{dd}, J=8.6,1.8 \mathrm{~Hz}, 1 \mathrm{H}), 6.11(\mathrm{~d}, J=1.0 \mathrm{~Hz}, 1 \mathrm{H}), 5.98(\mathrm{~d}, J=1.4 \mathrm{~Hz}, 1 \mathrm{H}), 5.31(\mathrm{~d}, J=1.4$ $\mathrm{Hz}, 1 \mathrm{H}), 4.89(\mathrm{~d}, J=1.2 \mathrm{~Hz}, 2 \mathrm{H}), 4.14(\mathrm{ddd}, J=5.8,4.2,1.3 \mathrm{~Hz}, 2 \mathrm{H}), 4.07$ (ddd, $J=6.0,4.1,1.3 \mathrm{~Hz}, 2 \mathrm{H}), 2.72(\mathrm{~s}, 3 \mathrm{H})$;

${ }^{13} \mathrm{C}$ NMR $\left(75 \mathrm{MHz}\right.$, Acetone- $\left.d_{6}\right) \delta 159.6,150.0,149.3,148.8,137.2,135.3,133.2,130.0,129.7,129.1,127.0,126.3$, 126.1, 123.1, 120.4, 119.5, 115.0, 109.8, 96.9, 65.2, 65.1, 42.6, 25.4; IR $\left(\mathrm{cm}^{-1}\right): 3052,2958,2924,2358,1592,1481$, $1371,1107,903,768$; HRMS $\left(\right.$ ESI $^{+}$) for $\mathrm{C}_{23} \mathrm{H}_{21} \mathrm{~N}_{2} \mathrm{O}[\mathrm{M}+\mathrm{H}]^{+}$: calcd 341.1654 found 341.1646. 
Protocol A. Column chromatography on silica gel afforded 36mg of the product as a yellow solid (0.10 mmol, yield $62 \%)$; TLC $\left(\mathrm{SiO}_{2}, 7 / 3\right.$ Cyclohexane/EtOAc $) ; \mathrm{R}_{\mathrm{f}}=0.80 ; \mathrm{m} . \mathrm{p}=131^{\circ} \mathrm{C} ;{ }^{1} \mathrm{H} \mathrm{NMR}\left(300 \mathrm{MHz}, \mathrm{CDCl}_{3}\right) \delta 7.50(\mathrm{~s}, 1 \mathrm{H}), 7.21$ $-7.10(\mathrm{~m}, 2 \mathrm{H}), 6.54(\mathrm{~s}, 2 \mathrm{H}), 6.13(\mathrm{~s}, 1 \mathrm{H}), 5.35(\mathrm{~d}, J=2.3 \mathrm{~Hz}, 1 \mathrm{H}), 5.29(\mathrm{~d}, J=2.4 \mathrm{~Hz}, 1 \mathrm{H}), 4.91(\mathrm{~s}, 2 \mathrm{H}), 4.10(\mathrm{dd}, J=$ 6.4, $4.2 \mathrm{~Hz}, 2 \mathrm{H}), 4.02(\mathrm{dd}, J=6.0,4.4 \mathrm{~Hz}, 2 \mathrm{H}), 3.81(\mathrm{~s}, 3 \mathrm{H}), 3.72(\mathrm{~s}, 6 \mathrm{H}) ;{ }^{13} \mathrm{C} \mathrm{NMR}\left(75 \mathrm{MHz}, \mathrm{CDCl}_{3}\right) \delta 152.8(2 \mathrm{C})$, 151.1, 138.3, 137.8, 136.0, 133.6 (2C), 127.8, 121.9, 120.3, 112.5, 108.1, 105.9 (2C), 96.2, 65.0, 64.6, 60.9, 56.1 (2C), 41.9; IR $\left(\mathrm{cm}^{-1}\right)$ : 2957, 2933, 1579, 1504, 1459, 1411, 1367, 1340, 1235, 1125, 1006; HRMS (ESI $)$ for $\mathrm{C}_{22} \mathrm{H}_{24} \mathrm{NO}_{4}\left[\mathrm{M}_{+}\right.$ $\mathrm{H}]^{+}$: calcd 366.1705 found 366.1696 .

\subsubsection{Methyl-N-(2-methylquinolin-4-yl)-3,4-dihydro-1H-[1,4]oxazino[4,3-a]indol-8-amine 12c}

Protocol B followed by a $N$-Methylation reaction. Column chromatography on silica gel afforded 43 mg of the product as a beige solid (0.12 mmol, yield 63\%); TLC $\left(\mathrm{SiO}_{2}, 9 / 1 \mathrm{DCM} / \mathrm{MeOH}\right) ; \mathrm{R}_{\mathrm{f}}=0.48 ; \mathrm{m} . \mathrm{p}=190{ }^{\circ} \mathrm{C} ;{ }^{1} \mathrm{H} \mathrm{NMR}(300 \mathrm{MHz}$, Methanol- $\left.d_{4}\right) \delta 7.77(\mathrm{dd}, J=8.3,1.4 \mathrm{~Hz}, 1 \mathrm{H}), 7.53-7.35(\mathrm{~m}, 2 \mathrm{H}), 7.25(\mathrm{dd}, J=8.7,1.7 \mathrm{~Hz}, 1 \mathrm{H}), 7.18-7.11(\mathrm{~m}, 1 \mathrm{H})$, $6.96(\mathrm{~s}, 1 \mathrm{H}), 6.95-6.85(\mathrm{~m}, 2 \mathrm{H}), 6.05(\mathrm{~s}, 1 \mathrm{H}), 4.88(\mathrm{~s}, 2 \mathrm{H}), 4.16-4.06(\mathrm{~m}, 2 \mathrm{H}), 4.04-3.95(\mathrm{~m}, 2 \mathrm{H}), 3.48(\mathrm{~s}, 3 \mathrm{H}), 2.66$ $(\mathrm{s}, 3 \mathrm{H}) ;{ }^{13} \mathrm{C}$ NMR $\left(75 \mathrm{MHz}\right.$, Methanol- $\left.d_{4}\right) \delta 158.5,155.1,147.8,143.8,134.5,134.0,128.8,128.7,126.1,125.6,123.3$, 120.7, 117.9, 115.3, 109.3, 108.4, 95.5, 64.2 (2C), 43.5, 41.5, 22.9; IR (cm $\left.{ }^{-1}\right): 2924,1585,1480,1415,1337,1092,979$, 765; HRMS $\left(\mathrm{ESI}^{+}\right.$) for $\mathrm{C}_{22} \mathrm{H}_{22} \mathrm{~N}_{3} \mathrm{O}[\mathrm{M}+\mathrm{H}]^{+}$: calcd 344.1757 found 344.1758

\subsubsection{N-Methyl-N-(3,4,5-trimethoxyphenyl)-3,4-dihydro-1H-[1,4]oxazino[4,3-a]indol-8-amine 12d}

Protocol B followed by a $N$-Methylation reaction. Column chromatography on silica gel afforded 20 mg of the product as a white off solid (0.10 mmol, yield 35\%); TLC $\left(\mathrm{SiO}_{2}, 6 / 4\right.$ Cyclohexane/EtOAc $) ; \mathrm{R}_{\mathrm{f}}=0.63 ; \mathrm{m} . \mathrm{p}=147{ }^{\circ} \mathrm{C} ;{ }^{1} \mathrm{H} \mathrm{NMR}$ $\left(300 \mathrm{MHz}\right.$, Acetone- $\left.d_{6}\right) \delta 7.34(\mathrm{~d}, J=8.7 \mathrm{~Hz}, 1 \mathrm{H}), 7.31(\mathrm{~d}, J=1.9 \mathrm{~Hz}, 1 \mathrm{H}), 6.96(\mathrm{dd}, J=8.6,2.0 \mathrm{~Hz}, 1 \mathrm{H}), 6.18(\mathrm{~s}, 1 \mathrm{H})$, $6.05(\mathrm{~s}, 2 \mathrm{H}), 4.93(\mathrm{~s}, 2 \mathrm{H}), 4.17(\mathrm{dd}, J=5.8,3.8 \mathrm{~Hz}, 2 \mathrm{H}), 4.13-4.06(\mathrm{~m}, 2 \mathrm{H}), 3.66(\mathrm{~s}, 6 \mathrm{H}), 3.64(\mathrm{~s}, 3 \mathrm{H}), 3.28(\mathrm{~s}, 3 \mathrm{H})$; ${ }^{13} \mathrm{C}$ NMR (75 MHz, Acetone- $d_{6}$ ) $\delta 154.5$ (2C), 148.2, 143.3, 135.1 (2C), 134.8, 129.9, 120.3, 117.3, 110.3, 96.5, 95.1 (2C), 65.2 (2C), 60.6, 56.3 (2C), 42.6, 41.6; IR ( $\left.\mathrm{cm}^{-1}\right): 2933,2837,2825,1604,1583,1508,1240,1173,1008,979$; HRMS $\left(\mathrm{ESI}^{+}\right.$) for $\mathrm{C}_{21} \mathrm{H}_{25} \mathrm{~N}_{2} \mathrm{O}_{4}[\mathrm{M}+\mathrm{H}]^{+}$: calcd 369.1814 found 369.1817 .

\subsubsection{4-((3,4-Dihydro-1H-[1,4]oxazino[4,3-a]indol-8-yl)(methyl)amino)quinoline-2-carbonitrile 12e}

Protocol B followed by a $N$-Methylation reaction. Column chromatography on silica gel afforded $20 \mathrm{mg}$ of the product as a yellow solid (0.05 mmol, yield 30\%); $\mathrm{TLC}\left(\mathrm{SiO}_{2}, 6 / 4 \mathrm{Cyclohexane} / \mathrm{AcOEt}\right) ; \mathrm{R}_{\mathrm{f}}=0.46 ; \mathrm{m} \cdot \mathrm{p}=224^{\circ} \mathrm{C} ;{ }^{1} \mathrm{H} \mathrm{NMR}$ $\left(300 \mathrm{MHz}\right.$, Acetone-d $\left._{6}\right) \delta 7.92(\mathrm{~d}, J=8.5 \mathrm{~Hz}, 1 \mathrm{H}), 7.67-7.59(\mathrm{~m}, 1 \mathrm{H}), 7.61-7.52(\mathrm{~m}, 1 \mathrm{H}), 7.42(\mathrm{~s}, 1 \mathrm{H}), 7.38(\mathrm{~d}, J=$ $8.5 \mathrm{~Hz}, 1 \mathrm{H}), 7.28(\mathrm{~d}, J=2.3 \mathrm{~Hz}, 1 \mathrm{H}), 7.16(\mathrm{ddd}, J=8.4,6.7,1.4 \mathrm{~Hz}, 1 \mathrm{H}), 7.02(\mathrm{dd}, J=8.6,2.3 \mathrm{~Hz}, 1 \mathrm{H}), 6.14(\mathrm{~s}, 1 \mathrm{H})$, $4.92(\mathrm{~d}, J=1.1 \mathrm{~Hz}, 2 \mathrm{H}), 4.24-4.15(\mathrm{~m}, 2 \mathrm{H}), 4.15-4.08(\mathrm{~m}, 2 \mathrm{H}), 3.59(\mathrm{~s}, 3 \mathrm{H}) ;{ }^{13} \mathrm{C} \mathrm{NMR}\left(75 \mathrm{MHz}, \mathrm{CDCl}_{3}\right) \delta 155.0$, 150.0 (2C), 143.6, 134.8, 134.3, 130.4, 129.9, 129.0, 126.7, 125.8, 123.0, 118.6, 116.2, 110.8, 110.1, 109.9, 96.3, 65.0, 64.6, 44.7, 42.0; IR $\left(\mathrm{cm}^{-1}\right): 2924,2853,2235,1716,1568,1093,800 ; \mathrm{HRMS}\left(\mathrm{ESI}^{+}\right)$for $\mathrm{C}_{22} \mathrm{H}_{19} \mathrm{~N}_{4} \mathrm{O}[\mathrm{M}+\mathrm{H}]^{+}: \mathrm{calcd}$ 355.1553 found 355.1558 .

4.2.4.14. N-(2-Chloro-6,7-dimethoxyquinazolin-4-yl)-N-methyl-3,4-dihydro-1H-[1,4]oxazino[4,3-a]indol-8-amine 12f

Protocol B followed by a $N$-Methylation reaction. Column chromatography on silica gel afforded 25 mg of the product as off-white solid (0.06 mmol, yield 37\%); TLC $\left(\mathrm{SiO}_{2}, 5 / 5\right.$ Cyclohexane/AcOEt $) ; \mathrm{R}_{\mathrm{f}}=0.75 ; \mathrm{m} \cdot \mathrm{p}=218{ }^{\circ} \mathrm{C} ;{ }^{1} \mathrm{H} \mathrm{NMR}$ $\left(400 \mathrm{MHz}\right.$, Acetone-d $\left._{6}\right) \delta 7.55(\mathrm{dt}, J=8.6,0.7 \mathrm{~Hz}, 1 \mathrm{H}), 7.51(\mathrm{dd}, J=2.1,0.6 \mathrm{~Hz}, 1 \mathrm{H}), 7.19(\mathrm{dd}, J=8.5,2.1 \mathrm{~Hz}, 1 \mathrm{H})$, $6.98(\mathrm{~s}, 1 \mathrm{H}), 6.26(\mathrm{~d}, J=1.0 \mathrm{~Hz}, 1 \mathrm{H}), 6.14(\mathrm{~s}, 1 \mathrm{H}), 4.96(\mathrm{~d}, J=1.1 \mathrm{~Hz}, 2 \mathrm{H}), 4.24-4.13(\mathrm{~m}, 4 \mathrm{H}), 3.88(\mathrm{~s}, 3 \mathrm{H}), 3.61(\mathrm{~s}$, 3H), 2.88 (s, 3H); ${ }^{13} \mathrm{C}$ NMR (101 MHz, Acetone) $\delta$ 162.3, 155.7, 155.2, 151.3, 148.1, 141.0, 136.6, 136.2, 130.0, 120.8, 119.3, 111.3, 109.4, 107.4, 106.7, 97.0, 65.1 (2C), 56.2, 55.0, 43.3, 42.8; IR ( $\left.\mathrm{cm}^{-1}\right): 2927,1572,1509,1481,1338$, 1252, 1147, 957; HRMS (ESI ${ }^{+}$) for $\mathrm{C}_{22} \mathrm{H}_{22} \mathrm{ClN}_{4} \mathrm{O}_{3}[\mathrm{M}+\mathrm{H}]^{+}$: calcd 425.1380 found 425.1369 . 
Protocol B followed by a $N$-Methylation reaction. Column chromatography on silica gel afforded 35 mg of the product as a light brown solid (0.10 mmol, yield 35\%); $\mathrm{TLC}\left(\mathrm{SiO}_{2}, 8 / 2\right.$ Cyclohexane/EtOAc $) ; \mathrm{R}_{\mathrm{f}}=0.50 ; \mathrm{m} . \mathrm{p}=191{ }^{\circ} \mathrm{C} ;{ }^{1} \mathrm{H}$ $\operatorname{NMR}\left(300 \mathrm{MHz}, \mathrm{CD}_{2} \mathrm{Cl}_{2}\right) \delta 7.65(\mathrm{dd}, J=8.4,1.4 \mathrm{~Hz}, 1 \mathrm{H}), 7.44(\mathrm{ddd}, J=8.4,6.8,1.5 \mathrm{~Hz}, 1 \mathrm{H}), 7.36(\mathrm{~d}, J=2.1 \mathrm{~Hz}, 1 \mathrm{H})$, $7.31(\mathrm{dd}, J=8.6,0.8 \mathrm{~Hz}, 1 \mathrm{H}), 7.01(\mathrm{dd}, J=8.6,2.1 \mathrm{~Hz}, 1 \mathrm{H}), 6.93(\mathrm{dd}, J=8.6,1.5 \mathrm{~Hz}, 1 \mathrm{H}), 6.80(\mathrm{ddd}, J=8.4,6.8,1.4$ $\mathrm{Hz}, 1 \mathrm{H}), 6.27-6.06(\mathrm{~m}, 1 \mathrm{H}), 4.95(\mathrm{~d}, J=1.2 \mathrm{~Hz}, 2 \mathrm{H}), 4.16(\mathrm{td}, J=4.7,3.9,1.5 \mathrm{~Hz}, 2 \mathrm{H}), 4.12-4.00(\mathrm{~m}, 2 \mathrm{H}), 3.62(\mathrm{~s}$, 3H), $2.65(\mathrm{~s}, 3 \mathrm{H}) ;{ }^{13} \mathrm{C}$ NMR $\left(75 \mathrm{MHz}, \mathrm{CD}_{2} \mathrm{Cl}_{2}\right) \delta 163.7,162.3,152.6,142.1,135.5,135.3,131.9,129.4,127.9,127.0$, 124.0, 120.2, 118.3, 115.4, 110.4, 96.6, 65.3, 65.1, 43.6, 42.5, 26.7; IR ( $\left.\mathrm{cm}^{-1}\right): 2858,1613,1483,1383,1092,766$; HRMS $\left(\mathrm{ESI}^{+}\right.$) for $\mathrm{C}_{21} \mathrm{H}_{21} \mathrm{~N}_{4} \mathrm{O}\left[\mathrm{M}+\mathrm{H}^{+}\right.$: calcd 345.1715 found 345.1716 .

Bromoindole 14a was $N$-alkylated as above (using 2 eq of $\mathrm{NaH}$ and 1.2 eq of EtI or MeI) and the crude product was then charged in a round bottom flask under argon with $1.1 \mathrm{eq}$ of $\mathrm{TBDMsCl}$ and 1.1 eq of imidazole in dry DMF at room temperature overnight. A solution of saturated $\mathrm{NH}_{4} \mathrm{Cl}$ was added by small portion and the mixture was extracted with EtOAc (3x). The organic layers were then washed twice with brine, dried over $\mathrm{MgSO}_{4}$, concentrated in vacuum and purified by silica gel chromatography to give $\mathbf{1 4 b}$ or $\mathbf{1 4 c}$ as solids.

\subsubsection{5-Bromo-2-(((tert-butyldimethylsilyl)oxy)methyl)-1-ethyl-1H-indole 14b}

Column chromatography on silica gel afforded $715 \mathrm{mg}$ of the product as a white solid (1.94 mmol, yield 97\%); TLC $\left(\mathrm{SiO}_{2}, 7 / 3\right.$ Cyclohexane/EtOAc $) ; \mathrm{R}_{\mathrm{f}}=0.14 ; \mathrm{m} . \mathrm{p}=76{ }^{\circ} \mathrm{C} ;{ }^{1} \mathrm{H}$ NMR $(200 \mathrm{MHz}$, Chloroform-d) $\delta 7.70(\mathrm{~d}, J=1.8 \mathrm{~Hz}$, $1 \mathrm{H}), 7.33-7.24(\mathrm{~m}, 1 \mathrm{H}), 7.19(\mathrm{~d}, J=8.7 \mathrm{~Hz}, 1 \mathrm{H}), 6.32(\mathrm{~s}, 1 \mathrm{H}), 4.82(\mathrm{~s}, 2 \mathrm{H}), 4.24(\mathrm{q}, J=7.2 \mathrm{~Hz}, 2 \mathrm{H}), 1.40(\mathrm{t}, J=7.2$ $\mathrm{Hz}, 3 \mathrm{H}), 0.92$ (s, 9H), 0.09 (s, 6H); ${ }^{13} \mathrm{C} \mathrm{NMR}\left(75 \mathrm{MHz}, \mathrm{CDCl}_{3}\right) \delta$ 139.6, 135.5, 129.2, 124.2, 123.2, 112.5, 110.6, 100.4, 58.0, 38.5, 25.9 (3C), 18.3, 15.3, -5.3 (2C); IR ( $\left.\mathrm{cm}^{-1}\right): 2954,2929,2857,1471,1446,1412,1140,1051,833$, 779; HRMS $\left(\mathrm{ESI}^{+}\right.$) for $\mathrm{C}_{17} \mathrm{H}_{27} \mathrm{BrNOSi}[\mathrm{M}+\mathrm{H}]^{+}$: calcd 368.1040 found 368.1040 .

\subsubsection{5-Bromo-2-(((tert-butyldimethylsilyl)oxy)methyl)-1-methyl-1H-indole 14c}

Column chromatography on silica gel afforded $115 \mathrm{mg}$ of the product as a white solid (1.13 mmol, yield 90\%); TLC $\left(\mathrm{SiO}_{2}, 7 / 3\right.$ Cyclohexane/EtOAc $) ; \mathrm{R}_{\mathrm{f}}=0.13 ; \mathrm{m} . \mathrm{p}=82{ }^{\circ} \mathrm{C} ;{ }^{1} \mathrm{H}$ NMR $(300 \mathrm{MHz}$, Chloroform- $d) \delta 7.62(\mathrm{~d}, J=1.8 \mathrm{~Hz}$, $1 \mathrm{H}), 7.21(\mathrm{dd}, J=8.7,1.9 \mathrm{~Hz}, 1 \mathrm{H}), 7.10(\mathrm{~d}, J=8.7 \mathrm{~Hz}, 1 \mathrm{H}), 6.25(\mathrm{~s}, 1 \mathrm{H}), 4.75(\mathrm{~s}, 2 \mathrm{H}), 3.69$ (s, 3H), $0.84(\mathrm{~s}, 9 \mathrm{H}),-0.00$ $(\mathrm{s}, 6 \mathrm{H}) ;{ }^{13} \mathrm{C}$ NMR $\left(75 \mathrm{MHz}, \mathrm{CDCl}_{3}\right) \delta 140.2$ (2C), 129.0, 124.3, 123.1, 112.5, 110.4, 100.2, 58.0, 30.1, 25.8 (3C), 18.2, -5.3 (2C); IR ( $\left.\mathrm{cm}^{-1}\right): 2948,2925,2853,1462,1388,1248,1142,1052,854 ; \mathrm{HRMS}\left(\mathrm{ESI}^{+}\right)$for $\mathrm{C}_{16} \mathrm{H}_{25} \mathrm{BrNOSi}[\mathrm{M}+\mathrm{H}]^{+}$: calcd 354.0883 found 354.0885 .

Bromoindole 14a was charged in a round bottom flask under argon with 2.5 eq of $\mathrm{NaH}$ in dry $\mathrm{DMF}$ at $0{ }^{\circ} \mathrm{C}$ for $30 \mathrm{~min}$. Then, 3 eq of MeI were slowly injected and the mixture was stirred at room temperature for 2 h. At $0{ }^{\circ} \mathrm{C}$ a small quantity of water and a solution of saturated $\mathrm{NH}_{4} \mathrm{Cl}$ were added by small portions before extraction with EtOAc (3x). The organic layers were then washed twice with brine and dried over $\mathrm{MgSO}_{4}$. After concentration, the crude product was purified by silica gel chromatography (95/5 to 85/15 cyclohexane/EtOAc). Column chromatography on silica gel afforded $550 \mathrm{mg}$ of the product as a pink pale solid (2.17 mmol, yield 87\%); TLC ( $\mathrm{SiO}_{2}, 6 / 4$ Cyclohexane/EtOAc ); $\mathrm{R}_{\mathrm{f}}$ $=0.37 ; \mathrm{m} . \mathrm{p}=77^{\circ} \mathrm{C} ;{ }^{1} \mathrm{H}$ NMR $\left(300 \mathrm{MHz}\right.$, Methanol- $\left.d_{4}\right) \delta 7.64(\mathrm{~d}, J=1.9 \mathrm{~Hz}, 1 \mathrm{H}), 7.28(\mathrm{~d}, J=8.7 \mathrm{~Hz}, 1 \mathrm{H}), 7.24(\mathrm{dd}, J$ $=8.7,1.8 \mathrm{~Hz}, 1 \mathrm{H}), 6.42(\mathrm{~s}, 1 \mathrm{H}), 4.61(\mathrm{~s}, 2 \mathrm{H}), 3.74(\mathrm{~s}, 3 \mathrm{H}), 3.35(\mathrm{~s}, 3 \mathrm{H}) . ;{ }^{13} \mathrm{C} \mathrm{NMR}(75 \mathrm{MHz}, \mathrm{MeOD}) \delta 138.7,138.3$, 135.5, 125.5, 123.9, 113.4, 111.9, 103.2, 67.2, 57.8, 30.2; IR $\left(\mathrm{cm}^{-1}\right): 2926,1690,1471,1400,1333,1142,1088,866$; HRMS (APCI) for $\mathrm{C}_{11} \mathrm{H}_{13} \mathrm{BrNO}[\mathrm{M}+\mathrm{H}]^{+}$: calcd 254.0181 found 254.0174.

\subsubsection{5-Bromo-2-((methoxymethoxy)methyl)-1-methyl-1H-indole 14e}

Bromoindole 14a was $N$-methylated using 2 eq of $\mathrm{NaH}$ and 1.2 eq of MeI as above and the crude product was next charged in a round bottom flask under argon with 3 eq of DIPEA in dry DCM at room temperature for 20 min. Then, 2 
eq of $\mathrm{MOMCl}$ were injected, and the reaction was stirred at $50{ }^{\circ} \mathrm{C}$ for $2 \mathrm{~h}$. After completion, the reaction was neutralized with water, with 3 drops of $\mathrm{HCl}(1 \mathrm{~N})$ and was extracted with DCM. The combined organic layers were then washed twice with brine and were dried over $\mathrm{MgSO}_{4}$. After concentration, the crude product was purified by silica gel chromatography (95/5 to 85/15 cyclohexane/EtOAc). Column chromatography on silica gel afforded $1067 \mathrm{mg}$ of the product as a white solid (3.75 mmol, yield 91\%); TLC $\left(\mathrm{SiO}_{2}, 7 / 3\right.$ Cyclohexane/EtOAc $) ; \mathrm{R}_{\mathrm{f}}=0.45 ; \mathrm{m} . \mathrm{p}=65{ }^{\circ} \mathrm{C} ;{ }^{1} \mathrm{H}$ NMR $\left(300 \mathrm{MHz}\right.$, Acetone- $\left.d_{6}\right) \delta 7.69(\mathrm{~d}, J=1.8 \mathrm{~Hz}, 1 \mathrm{H}), 7.35(\mathrm{~d}, J=8.7 \mathrm{~Hz}, 1 \mathrm{H}), 7.26(\mathrm{dd}, J=8.7,1.9 \mathrm{~Hz}, 1 \mathrm{H}), 6.47$ $(\mathrm{s}, 1 \mathrm{H}), 4.74(\mathrm{~s}, 2 \mathrm{H}), 4.67$ (s, 2H), $3.80(\mathrm{~s}, 3 \mathrm{H}), 3.37$ (s, 3H); ${ }^{13} \mathrm{C}$ NMR (75 MHz, Acetone) $\delta$ 138.8, 137.7, 130.0, 124.9, 123.6, 112.9, 112.0, 102.7, 96.0, 61.4, 55.5, 30.3; IR ( $\left.\mathrm{cm}^{-1}\right): 2941,2849,1470,1399,1332,1146,1097,1027,912,865$, 787; HRMS (APCI) for $\mathrm{C}_{12} \mathrm{H}_{15} \mathrm{BrNO}_{2}[\mathrm{M}+\mathrm{H}]^{+}$: calcd 284.0286 found 284.0281 .

\subsubsection{9. (1-Ethyl-5-(1-(2-methylquinolin-4-yl)vinyl)-1H-indol-2-yl)methanol 15a}

Protocol A followed by a desilylation reaction. Column chromatography on silica gel afforded $30 \mathrm{mg}$ of the product as a white-off solid (0.09 mmol, yield 65\%) TLC $\left(\mathrm{SiO}_{2}, 6 / 4\right.$ cyclohexane/EtOAc); $\mathrm{R}_{\mathrm{f}}=0.84 ;$ m.p. $=182{ }^{\circ} \mathrm{C} ;{ }^{1} \mathrm{H} \mathrm{NMR}(300$ $\left.\mathrm{MHz}, \mathrm{CD}_{2} \mathrm{Cl}_{2}\right) \delta 7.97(\mathrm{~d}, J=8.5 \mathrm{~Hz}, 1 \mathrm{H}), 7.75(\mathrm{~d}, J=7.9 \mathrm{~Hz}, 1 \mathrm{H}), 7.58(\mathrm{ddd}, J=8.3,6.7,1.4 \mathrm{~Hz}, 1 \mathrm{H}), 7.37(\mathrm{~s}, 1 \mathrm{H})$, $7.34-7.23(\mathrm{~m}, 4 \mathrm{H}), 6.29(\mathrm{~s}, 1 \mathrm{H}), 6.11-5.89(\mathrm{~m}, 1 \mathrm{H}), 5.33(\mathrm{br} \mathrm{s}, 1 \mathrm{H}), 4.76(\mathrm{~s}, 2 \mathrm{H}), 4.26(\mathrm{q}, J=7.2 \mathrm{~Hz}, 2 \mathrm{H}), 2.73(\mathrm{~s}$, 3H), $1.39(\mathrm{t}, J=7.2 \mathrm{~Hz}, 3 \mathrm{H}) ;{ }^{13} \mathrm{C}$ NMR $\left(75 \mathrm{MHz}, \mathrm{CD}_{2} \mathrm{Cl} 2\right) \delta 159.5,149.9,148.8,148.0,140.1,137.4,132.3,129.5$, $129.3,128.1,126.8,126.2,125.8,123.1,121.1,120.0,115.0,110.0,102.2,57.8,39.1,25.6,15.9 ; I\left(\mathrm{~cm}^{-1}\right): 3247$, 2958, 2924, 2854, 1593, 1482, 1378, 1260, 1081, 1013, 797; HRMS (ESI ${ }^{+}$) for $\mathrm{C}_{23} \mathrm{H}_{23} \mathrm{~N}_{2} \mathrm{O}\left[\mathrm{M}+\mathrm{H}^{+}\right.$: calcd 343.1805 found 343.1809 .

\subsubsection{0. (1-Ethyl-5-(1-(3,4,5-trimethoxyphenyl)vinyl)-1H-indol-2-yl)methanol $\mathbf{1 5 b}$}

Protocol A followed by a desilylation reaction. Column chromatography on silica gel afforded 40 mg of the product as a orange yellow solid (0.11 mmol, yield 50\%); TLC $\left(\mathrm{SiO}_{2}, 7 / 3\right.$ Cyclohexane/AcOEt $) ; \mathrm{R}_{\mathrm{f}}=0.90 ; \mathrm{m} . \mathrm{p}=53{ }^{\circ} \mathrm{C} ;{ }^{1} \mathrm{H} \mathrm{NMR}$ (400 MHz, Acetone- $\left.d_{6}\right) \delta 7.49(\mathrm{dd}, J=1.7,0.7 \mathrm{~Hz}, 1 \mathrm{H}), 7.38(\mathrm{dt}, J=8.5,0.8 \mathrm{~Hz}, 1 \mathrm{H}), 7.17(\mathrm{dd}, J=8.5,1.8 \mathrm{~Hz}, 1 \mathrm{H})$, $6.65(\mathrm{~s}, 2 \mathrm{H}), 6.37(\mathrm{~d}, J=0.7 \mathrm{~Hz}, 1 \mathrm{H}), 5.38(\mathrm{~d}, J=1.6 \mathrm{~Hz}, 1 \mathrm{H}), 5.35(\mathrm{~d}, J=1.6 \mathrm{~Hz}, 1 \mathrm{H}), 4.78(\mathrm{~s}, 2 \mathrm{H}), 4.34(\mathrm{q}, J=7.1$ $\mathrm{Hz}, 2 \mathrm{H}), 3.76(\mathrm{~s}, 9 \mathrm{H}), 1.40(\mathrm{t}, J=7.2 \mathrm{~Hz}, 3 \mathrm{H}) ;{ }^{13} \mathrm{C}$ NMR (101 MHz, Acetone- $\left.d_{6}\right) \delta 154.0(2 \mathrm{C}), 152.4,141.2,139.2$, $\left.139.1,137.7,133.4,128.6,122.8,121.2,112.3,109.8,107.1(2 \mathrm{C}), 101.9,60.6,57.3,56.5(2 \mathrm{C}), 39.0,15.8 ; \mathrm{IR}_{(\mathrm{cm}}{ }^{-1}\right)$ : 3447, 2934, 1579, 1504, 1462, 1372, 1261, 1166, 1076; HRMS $\left(\mathrm{ESI}^{+}\right)$for $\mathrm{C}_{22} \mathrm{H}_{26} \mathrm{NO}_{4}[\mathrm{M}+\mathrm{H}]^{+}$: calcd 368.1856 found 368.1863 .

\subsubsection{1. (1-Ethyl-5-(methyl(2-methylquinolin-4-yl)amino)-1H-indol-2-yl)methanol 15c}

Protocol B followed by a $\mathrm{N}$-Methylation reaction and a desilylation step. Column chromatography on silica gel afforded $55 \mathrm{mg}$ of the product as a yellow solid $(0.16 \mathrm{mmol}$, yield $50 \%)$; TLC $\left(\mathrm{SiO}_{2}, 9 / 1 \mathrm{DCM} / \mathrm{MeOH}\right) ; \mathrm{R}_{\mathrm{f}}=0.76 ; \mathrm{m} . \mathrm{p}=177$ ${ }^{\circ} \mathrm{C} ;{ }^{1} \mathrm{H}$ NMR $(300 \mathrm{MHz}$, Chloroform- $d) \delta 7.98(\mathrm{~d}, J=8.4 \mathrm{~Hz}, 1 \mathrm{H}), 7.62(\mathrm{~d}, J=8.0 \mathrm{~Hz}, 1 \mathrm{H}), 7.50(\mathrm{t}, J=7.6 \mathrm{~Hz}, 1 \mathrm{H})$, $7.31(\mathrm{~d}, J=7.8 \mathrm{~Hz}, 1 \mathrm{H}), 7.27(\mathrm{~s}, 1 \mathrm{H}), 7.09$ (t, $J=7.5 \mathrm{~Hz}, 1 \mathrm{H}), 7.00(\mathrm{dd}, J=8.7,2.2 \mathrm{~Hz}, 1 \mathrm{H}), 6.92(\mathrm{~s}, 1 \mathrm{H}), 6.34(\mathrm{~s}, 1 \mathrm{H})$, $4.84(\mathrm{~s}, 2 \mathrm{H}), 4.31(\mathrm{q}, J=7.2 \mathrm{~Hz}, 2 \mathrm{H}), 3.53(\mathrm{~s}, 3 \mathrm{H}), 2.75(\mathrm{~s}, 3 \mathrm{H}), 1.47(\mathrm{t}, J=7.2 \mathrm{~Hz}, 3 \mathrm{H}) ;{ }^{13} \mathrm{C} \mathrm{NMR}\left(75 \mathrm{MHz}, \mathrm{CDCl}_{3}\right) \delta$ 159.0, 154.6, 143.7, 139.4, 134.1, 128.7, 128.3, 128.0, 125.3, 123.9, 121.6, 118.8, 114.9, 110.4, 110.3, 101.4, 57.2, 44.1, 38.5, 29.7, 25.2, 15.6; IR $\left(\mathrm{cm}^{-1}\right): 3241,2924,1585,1480,1414,765 ; \mathrm{HRMS}\left(\mathrm{ESI}^{+}\right)$for $\mathrm{C}_{22} \mathrm{H}_{24} \mathrm{~N}_{3} \mathrm{O}[\mathrm{M}+\mathrm{H}]^{+}$: calcd 346.1914 found 346.1899 .

\subsubsection{2. (1-Ethyl-5-(methyl(2-methylquinazolin-4-yl)amino)-1H-indol-2-yl)methanol 15d}

Protocol B followed by a $N$-Methylation reaction and a desilylation step. Column chromatography on silica gel afforded $40 \mathrm{mg}$ of the product as a pale yellow solid $(0.11 \mathrm{mmol}$, yield $33 \%)$; TLC $\left(\mathrm{SiO}_{2}, 95 / 5 \mathrm{DCM} / \mathrm{MeOH}\right) ; \mathrm{R}_{\mathrm{f}}=0.74 ; \mathrm{m} . \mathrm{p}=$ $63{ }^{\circ} \mathrm{C} ;{ }^{1} \mathrm{H}$ NMR $\left(300 \mathrm{MHz}, \mathrm{CD}_{2} \mathrm{Cl}_{2}\right) \delta 8.48(\mathrm{~s}, 1 \mathrm{H}), 8.08(\mathrm{br} \mathrm{s}, 1 \mathrm{H}), 7.89(\mathrm{~d}, J=8.2 \mathrm{~Hz}, 1 \mathrm{H}), 7.69-7.50(\mathrm{~m}, 1 \mathrm{H}), 7.48$ $-7.33(\mathrm{~m}, 1 \mathrm{H}), 7.06(\mathrm{~d}, J=8.6 \mathrm{~Hz}, 1 \mathrm{H}), 6.89(\mathrm{t}, J=7.8 \mathrm{~Hz}, 1 \mathrm{H}), 6.79(\mathrm{~d}, J=8.5 \mathrm{~Hz}, 1 \mathrm{H}), 6.42(\mathrm{~s}, 1 \mathrm{H}), 4.81(\mathrm{~s}, 2 \mathrm{H})$, 
$4.32(\mathrm{q}, J=6.4 \mathrm{~Hz}, 2 \mathrm{H}), 3.74(\mathrm{~s}, 3 \mathrm{H}), 2.75(\mathrm{~s}, 3 \mathrm{H}), 1.43(\mathrm{t}, J=7.0 \mathrm{~Hz}, 3 \mathrm{H}) ;{ }^{13} \mathrm{C} \mathrm{NMR}\left(75 \mathrm{MHz}, \mathrm{CD}_{2} \mathrm{Cl}_{2}\right) \delta 166.6$, 162.1, 146.2, 141.7, 138.9, 136.6, 133.8, 129.0, 127.5, 125.7, 123.3, 120.1, 118.6, 114.0, 111.7, 102.1, 57.5, 44.6, 39.3, 24.1, 15.8; IR $\left(\mathrm{cm}^{-1}: 3246,1584,1566,1498,1482,1385,1348,766\right.$; HRMS $\left(\mathrm{ESI}^{+}\right)$for $\mathrm{C}_{21} \mathrm{H}_{23} \mathrm{~N}_{4} \mathrm{O}[\mathrm{M}+\mathrm{H}]^{+}: \mathrm{calcd}$ 347.1872 found 347.1876 .

\subsubsection{3. (1-Ethyl-5-(methyl(3,4,5-trimethoxyphenyl)amino)-1H-indol-2-yl)methanol 15e}

Protocol B followed by a $N$-Methylation reaction and a desilylation step. Column chromatography on silica gel afforded $20 \mathrm{mg}$ of the product as a brown solid $(0.11 \mathrm{mmol}$, yield $13 \%) ; \mathrm{TLC}\left(\mathrm{SiO}_{2}, 7 / 3\right.$ Cyclohexane $\left./ \mathrm{EtOAc}\right) ; \mathrm{R}_{\mathrm{f}}=0.62 ; \mathrm{m} . \mathrm{p}=$ $104{ }^{\circ} \mathrm{C} ;{ }^{1} \mathrm{H}$ NMR $\left(300 \mathrm{MHz}\right.$, Acetone- $\left.d_{6}\right) \delta 7.35(\mathrm{~d}, J=4.2 \mathrm{~Hz}, 1 \mathrm{H}), 7.33(\mathrm{~d}, J=2.5 \mathrm{~Hz}, 1 \mathrm{H}), 7.05(\mathrm{dd}, J=8.8,1.6 \mathrm{~Hz}$, $1 \mathrm{H}), 6.40-6.28(\mathrm{~m}, 3 \mathrm{H}), 4.58(\mathrm{~s}, 2 \mathrm{H}), 4.24(\mathrm{q}, J=7.1 \mathrm{~Hz}, 2 \mathrm{H}), 3.72(\mathrm{~s}, 6 \mathrm{H}), 3.65(\mathrm{~s}, 3 \mathrm{H}), 3.32(\mathrm{~s}, 3 \mathrm{H}), 1.35(\mathrm{t}, J=7.1$ $\mathrm{Hz}, 3 \mathrm{H}) ;{ }^{13} \mathrm{C}$ NMR (75 MHz, Acetone- $\left.d_{6}\right) \delta 155.7$ (2C), 139.9, 137.0, 136.7, 129.1, 117.9, 117.6, 112.4, 110.7 (2C), 103.1, 94.3 (2C), 67.0, 60.7, 57.5, 56.2 (2C), 38.9, 15.7; IR $\left(\mathrm{cm}^{-1}\right): 3363,2854,2823,1604,1506,1463,1232,1213$, 1127, 1010; HRMS (ESI ${ }^{+}$) for $\mathrm{C}_{21} \mathrm{H}_{27} \mathrm{~N}_{2} \mathrm{O}_{4}\left[\mathrm{M}+\mathrm{H}^{+}\right.$: calcd 371.1971 found 371.1992.

4.2.4.24. (1-Methyl-5-(1-(2-methylquinolin-4-yl)vinyl)-1H-indol-2-yl)methanol $\mathbf{1 5 f}$

Protocol A followed by a desilylation reaction. Column chromatography on silica gel afforded $26 \mathrm{mg}$ of the product as a white-off solid (0.07 mmol, yield $40 \%) \mathrm{TLC}\left(\mathrm{SiO}_{2}, 5 / 5\right.$ cyclohexane/EtOAc); $\mathrm{R}_{\mathrm{f}}=0.83 ; \mathrm{m} . \mathrm{p} .=217{ }^{\circ} \mathrm{C} ;{ }^{1} \mathrm{H} \mathrm{NMR}(300$ MHz, DMSO-d $\left.d_{6}\right) \delta .95(\mathrm{~d}, J=8.4 \mathrm{~Hz}, 1 \mathrm{H}), 7.69-7.59(\mathrm{~m}, 1 \mathrm{H}), 7.58(\mathrm{~d}, J=8.3 \mathrm{~Hz}, 1 \mathrm{H}), 7.37(\mathrm{t}, J=4.2 \mathrm{~Hz}, 2 \mathrm{H}), 7.32$ $(\mathrm{d}, J=8.1 \mathrm{~Hz}, 1 \mathrm{H}), 7.28(\mathrm{~s}, 1 \mathrm{H}), 7.17(\mathrm{dd}, J=8.6,1.7 \mathrm{~Hz}, 1 \mathrm{H}), 6.27(\mathrm{~s}, 1 \mathrm{H}), 5.99(\mathrm{~s}, 1 \mathrm{H}), 5.29(\mathrm{~s}, 1 \mathrm{H}), 5.18(\mathrm{t}, J=5.2$ $\mathrm{Hz}, 1 \mathrm{H}), 4.59$ (d, $J=4.8 \mathrm{~Hz}, 2 \mathrm{H}), 3.71$ (s, 3H), 2.71 (s, 3H); ${ }^{13} \mathrm{C}$ NMR (75 MHz, DMSO) $\delta 158.6,148.7,147.6,146.8$, 141.4, 137.3, 130.8, 129.0, 128.6, 126.9, 125.7, 125.4, 124.9, 122.2, 119.6, 118.3, 114.6, 109.6, 100.4, 55.4, 29.7, 24.8. IR $\left(\mathrm{cm}^{-1}\right): 3252,2941,2924,1595,1488,1378,1072,1022 ;$ HRMS $\left(E S I^{+}\right)$for $\mathrm{C}_{22} \mathrm{H}_{21} \mathrm{~N}_{2} \mathrm{O}[\mathrm{M}+\mathrm{H}]^{+}:$calcd 329.1648 found 329.1651 .

\subsubsection{5. (1-Methyl-5-(1-(3,4,5-trimethoxyphenyl)vinyl)-1H-indol-2-yl)methanol 15g}

Protocol A followed by a desilylation reaction. Column chromatography on silica gel afforded $15 \mathrm{mg}$ of the product as a brown pale oil (0.04 mmol, yield 50\%); TLC $\left(\mathrm{SiO}_{2}, 5 / 5\right.$ Cyclohexane/AcOEt $) ; \mathrm{R}_{\mathrm{f}}=0.55 ;{ }^{1} \mathrm{H} \mathrm{NMR}(300 \mathrm{MHz}, \mathrm{Acetone}-$ $\left.d_{6}\right) \delta 7.49(\mathrm{~d}, J=1.8 \mathrm{~Hz}, 1 \mathrm{H}), 7.34(\mathrm{~d}, J=8.6 \mathrm{~Hz}, 1 \mathrm{H}), 7.17(\mathrm{dd}, J=8.5,1.7 \mathrm{~Hz}, 1 \mathrm{H}), 6.64(\mathrm{~s}, 2 \mathrm{H}), 6.39(\mathrm{~s}, 1 \mathrm{H}), 5.37$ $(\mathrm{d}, J=2.0 \mathrm{~Hz}, 2 \mathrm{H}), 4.78(\mathrm{~d}, J=5.5 \mathrm{~Hz}, 2 \mathrm{H}), 4.16(\mathrm{t}, J=5.6 \mathrm{~Hz}, 1 \mathrm{H}), 3.83(\mathrm{~s}, 3 \mathrm{H}), 3.78-3.73(\mathrm{~m}, 9 \mathrm{H}) ;{ }^{13} \mathrm{C} \mathrm{NMR}(75$ MHz, Acetone- $\left.d_{6}\right) \delta 154.0$ (2C), 152.3, 141.8, 139.2, 139.0, 138.8, 133.4, 128.3, 122.8, 121.1, 112.2, 109.6, 107.0 (2C), 101.6, 60.6, 57.2, 56.4 (2C), 27.5; IR $\left(\mathrm{cm}^{-1}\right): 3435,2933,1579,1412,1345,1236,1125,1005$; HRMS (ESI $)$ for $\mathrm{C}_{21} \mathrm{H}_{24} \mathrm{NO}_{4}[\mathrm{M}+\mathrm{H}]^{+}$: calcd 354.1700 found 354.1700 .

\subsubsection{6. (1-Methyl-5-(methyl(2-methylquinolin-4-yl)amino)-1H-indol-2-yl)methanol 15h}

Protocol B followed by a N-methylation reaction and a desilylation step. Column chromatography on silica gel afforded $20 \mathrm{mg}$ of the product as a deep yellow solid $(0.06 \mathrm{mmol}$, yield $45 \%)$; TLC $\left(\mathrm{SiO}_{2}, 8 / 2 \mathrm{DCM} / \mathrm{MeOH}\right) ; \mathrm{R}_{\mathrm{f}}=0.33 ; \mathrm{m} . \mathrm{p}=$ $192{ }^{\circ} \mathrm{C} ;{ }^{1} \mathrm{H}$ NMR $\left(300 \mathrm{MHz}\right.$, Methanol- $\left.d_{4}\right) \delta 7.77(\mathrm{~d}, J=9.0 \mathrm{~Hz}, 1 \mathrm{H}), 7.48-7.37(\mathrm{~m}, 2 \mathrm{H}), 7.31(\mathrm{~d}, J=8.7 \mathrm{~Hz}, 1 \mathrm{H})$, $7.17(\mathrm{~d}, J=2.2 \mathrm{~Hz}, 1 \mathrm{H}), 7.03-6.93(\mathrm{~m}, 2 \mathrm{H}), 6.92-6.86(\mathrm{~m}, 1 \mathrm{H}), 6.30(\mathrm{~s}, 1 \mathrm{H}), 4.71(\mathrm{~s}, 2 \mathrm{H}), 3.77(\mathrm{~s}, 3 \mathrm{H}), 3.50(\mathrm{~s}, 3 \mathrm{H})$, $2.67(\mathrm{~s}, 3 \mathrm{H}) ;{ }^{13} \mathrm{C}$ NMR $\left(75 \mathrm{MHz}\right.$, Methanol- $\left.d_{4}\right) \delta 159.8,156.6,149.0,144.6,142.0,137.3,130.2,129.5,127.4,127.2$, 124.7, 122.0, 120.2, 117.1, 111.4, 109.6, 102.2, 57.2, 45.0, 30.2, 24.2; IR (cm $\left.{ }^{-1}\right): 3226,2962,1637,1507,1428,1014$, 765; HRMS $\left(\mathrm{ESI}^{+}\right.$) for $\mathrm{C}_{21} \mathrm{H}_{22} \mathrm{~N}_{3} \mathrm{O}[\mathrm{M}+\mathrm{H}]^{+}$: calcd 332.1763 found 332.1758 .

4.2.4.27. N-(2-((Methoxymethoxy)methyl)-1-methyl-1H-indol-5-yl)-N,2-dimethylquinolin-4-amine 15i

Protocol B followed by a $\mathrm{N}$-methylation reaction. Column chromatography on silica gel afforded 145 mg of the product as a yellow powder (0.39 mmol, yield 73\%); TLC $\left(\mathrm{SiO}_{2}, 9 / 1 \mathrm{DCM} / \mathrm{MeOH}\right) ; \mathrm{R}_{\mathrm{f}}=0.45 ; \mathrm{m} . \mathrm{p}=122{ }^{\circ} \mathrm{C} ;{ }^{1} \mathrm{H} \mathrm{NMR}(300$ $\mathrm{MHz}, \mathrm{MeOD}) \delta 7.77(\mathrm{~d}, J=8.8 \mathrm{~Hz}, 1 \mathrm{H}), 7.48-7.34(\mathrm{~m}, 2 \mathrm{H}), 7.25(\mathrm{~d}, J=8.7 \mathrm{~Hz}, 1 \mathrm{H}), 7.14(\mathrm{~d}, J=2.2 \mathrm{~Hz}, 1 \mathrm{H}), 6.94$ 
(s, 1H), $6.94-6.90(\mathrm{~m}, 1 \mathrm{H}), 6.90-6.85(\mathrm{~m}, 1 \mathrm{H}), 6.29(\mathrm{~s}, 1 \mathrm{H}), 4.66(\mathrm{~s}, 2 \mathrm{H}), 4.63(\mathrm{~s}, 2 \mathrm{H}), 3.70(\mathrm{~s}, 3 \mathrm{H}), 3.45(\mathrm{~s}, 3 \mathrm{H})$, 3.36 (s, 3H), 2.65 (s, 3H); ${ }^{13} \mathrm{C}$ NMR (75 MHz, MeOD) $\delta 160.1,156.5,149.5,144.8,138.4,137.2,130.1,129.3,127.8$, 127.1, 124.7, 122.2, 120.4, 117.0, 111.4, 110.0, 103.9, 96.2, 61.9, 55.8, 44.9, 30.2, 24.5; IR $\left(\mathrm{cm}^{-1}\right): 2940,2828,1578$, 1480, 1083, 763, 731; HRMS (ESI ${ }^{+}$) for $\mathrm{C}_{23} \mathrm{H}_{26} \mathrm{~N}_{3} \mathrm{O}_{2}[\mathrm{M}+\mathrm{H}]^{+}$: calcd 376.2025 found 376.2021 .

\subsubsection{N-(2-(Methoxymethyl)-1-methyl-1H-indol-5-yl)-N,2-dimethylquinolin-4-amine $\mathbf{1 5 j}$}

Protocol B followed by a $N$-methylation reaction. Column chromatography on silica gel afforded $660 \mathrm{mg}$ of the product as a yellow solid (1.74 mmol, yield $84 \%)$; TLC $\left(\mathrm{SiO}_{2}, 9 / 1 \mathrm{DCM} / \mathrm{MeOH}\right) ; \mathrm{R}_{\mathrm{f}}=0.55 ; \mathrm{m} . \mathrm{p}=156{ }^{\circ} \mathrm{C} ;{ }^{1} \mathrm{H}$ NMR $(300$ $\left.\mathrm{MHz}, \mathrm{CDCl}_{3}\right) \delta 7.95(\mathrm{~d}, J=8.3 \mathrm{~Hz}, 1 \mathrm{H}), 7.55(\mathrm{~d}, J=8.5 \mathrm{~Hz}, 1 \mathrm{H}), 7.45(\mathrm{t}, J=7.6 \mathrm{~Hz}, 1 \mathrm{H}), 7.26-7.15(\mathrm{~m}, 2 \mathrm{H}), 7.02(\mathrm{t}$, $J=7.7 \mathrm{~Hz}, 1 \mathrm{H}), 6.94(\mathrm{dd}, J=8.7,1.8 \mathrm{~Hz}, 1 \mathrm{H}), 6.87(\mathrm{~s}, 1 \mathrm{H}), 6.35(\mathrm{~s}, 1 \mathrm{H}), 4.55(\mathrm{~s}, 2 \mathrm{H}), 3.73(\mathrm{~s}, 3 \mathrm{H}), 3.48(\mathrm{~s}, 3 \mathrm{H}), 3.35$ (s, 3H), $2.72(\mathrm{~s}, 3 \mathrm{H}) ;{ }^{13} \mathrm{C} \mathrm{NMR}\left(75 \mathrm{MHz}, \mathrm{CDCl}_{3}\right) \delta 158.9,154.6,149.0,143.8,136.8,135.4,128.7,128.3,127.7,125.3$, 123.9, 121.6, 118.9, 114.9, 110.3, 110.1, 102.9, 66.4, 57.5, 44.1, 29.9, 25.2; IR $\left(\mathrm{cm}^{-1}\right): 2924,2881,1585,1481,1083$, 764, 731 ; HRMS (ESI ${ }^{+}$) for $\mathrm{C}_{22} \mathrm{H}_{24} \mathrm{~N}_{3} \mathrm{O}[\mathrm{M}+\mathrm{H}]^{+}$: calcd 346.1919 found 346.1910 .

\subsubsection{2-(Methoxymethyl)-N,1-dimethyl-N-(3,4,5-trimethoxyphenyl)-1H-indol-5-amine $\mathbf{1 5 k}$}

Protocol B followed by a $N$-methylation reaction. Column chromatography on silica gel afforded $160 \mathrm{mg}$ of the product as a pale brown oil $(0.43 \mathrm{mmol}$, yield $55 \%)$; $\mathrm{TLC}\left(\mathrm{SiO}_{2}, 6 / 4\right.$ Cyclohexane/AcOEt $) ; \mathrm{R}_{\mathrm{f}}=0.55 ;{ }^{1} \mathrm{H}$ NMR (300 MHz, Chloroform- $d$ ) $\delta 7.39(\mathrm{~d}, J=1.9 \mathrm{~Hz}, 1 \mathrm{H}), 7.28(\mathrm{~d}, J=8.7 \mathrm{~Hz}, 1 \mathrm{H}), 7.06(\mathrm{dd}, J=8.7,2.1 \mathrm{~Hz}, 1 \mathrm{H}), 6.45(\mathrm{~s}, 1 \mathrm{H}), 6.02(\mathrm{~s}$, 2H), $4.60(\mathrm{~s}, 2 \mathrm{H}), 3.79(\mathrm{~s}, 3 \mathrm{H}), 3.78(\mathrm{~s}, 3 \mathrm{H}), 3.73(\mathrm{~s}, 6 \mathrm{H}), 3.38(\mathrm{~s}, 3 \mathrm{H}), 3.32(\mathrm{~s}, 3 \mathrm{H}) ;{ }^{13} \mathrm{C} \mathrm{NMR}\left(75 \mathrm{MHz}, \mathrm{CDCl}_{3}\right) \delta$ 153.4 (2C), 147.2, 141.7, 136.5, 135.8, 130.7, 127.9, 120.9, 117.1, 110.0, 102.9, 93.6 (2C), 66.5, 61.0, 57.5, 56.0 (2C), 41.4, 29.9; IR $\left(\mathrm{cm}^{-1}\right)$ : 2930, 2581, 1506, 1485, 1236, 1124, 1082, 975, 729; HRMS (ESI ${ }^{+}$) for $\mathrm{C}_{21} \mathrm{H}_{27} \mathrm{~N}_{2} \mathrm{O}_{4}[\mathrm{M}+\mathrm{H}]^{+}$: calcd 371.1971 found 371.1959 .

\subsubsection{2-(Methoxymethyl)-1-methyl-5-(1-(3,4,5-trimethoxyphenyl)vinyl)-1H-indole $\mathbf{1 5 1}$}

Protocol A. Column chromatography on silica gel afforded $115 \mathrm{mg}$ of the product as a pale yellow solid $(0.31 \mathrm{mmol}$, yield 80\%); TLC $\left(\mathrm{SiO}_{2}, 7 / 3\right.$ Cyclohexane/EtOAc $) ; \mathrm{R}_{\mathrm{f}}=0.59 ; \mathrm{m} . \mathrm{p}=123{ }^{\circ} \mathrm{C} ;{ }^{1} \mathrm{H}$ NMR $\left(300 \mathrm{MHz}\right.$, Acetone- $\left.d_{6}\right) \delta 7.52$ $(\mathrm{dd}, J=1.7,0.7 \mathrm{~Hz}, 1 \mathrm{H}), 7.36(\mathrm{dd}, J=8.6,0.8 \mathrm{~Hz}, 1 \mathrm{H}), 7.19(\mathrm{dd}, J=8.6,1.7 \mathrm{~Hz}, 1 \mathrm{H}), 6.65(\mathrm{~s}, 2 \mathrm{H}), 6.47(\mathrm{~s}, 1 \mathrm{H}), 5.44-$ $5.32(\mathrm{~m}, 2 \mathrm{H}), 4.61(\mathrm{~s}, 2 \mathrm{H}), 3.79(\mathrm{~s}, 3 \mathrm{H}), 3.76(\mathrm{~s}, 3 \mathrm{H}), 3.76(\mathrm{~s}, 6 \mathrm{H}), 3.34(\mathrm{~s}, 3 \mathrm{H}) ;{ }^{13} \mathrm{C}$ NMR $\left(75 \mathrm{MHz}\right.$, Acetone- $\left.d_{6}\right) \delta$ 154.0 (2C), 152.3, 139.2, 139.0 (2C), 138.9, 138.0, 133.6, 128.1, 123.1, 121.2, 112.4, 109.7, 107.0 (2C), 103.6, 66.9, 60.6, 57.5, 56.4 (2C); IR ( $\left.\mathrm{cm}^{-1}\right)$ : 2935, 2828, 2358, 1578, 1503, 1450, 1410, 1365, 1235, 1174, 1084; HRMS (ESI ${ }^{+}$) for $\mathrm{C}_{22} \mathrm{H}_{26} \mathrm{NO}_{4}[\mathrm{M}+\mathrm{H}]^{+}$:calcd 368.1862 found 368.1878 .

\subsection{Biolology}

\subsubsection{Cell Culture and Proliferation Assay}

Cancer cell lines were obtained from the American type Culture Collection (Rockville, MD) and were cultured according to the supplier's instructions. K562R (doxorubicin-resistant) leukemia cells were a generous gift from JP Marie (France). Briefly, human HCT-116 colorectal carcinoma cells were grown in Gibco McCoy's 5A supplemented with 10\% fetal calf serum and 1\% glutamine. A549 lung carcinoma, MDA-MB231 breast carcinoma, K562 and K562R leukemia cells were grown in RPMI 1640 supplemented with 10\% fetal calf serum and 1\% glutamine. U87-MG glioblastoma, Mia Paca-2 pancreatic carcinoma and HT29 colorectal carcinoma cells were grown in Dulbecco minimal essential medium (DMEM) containing $4.5 \mathrm{~g} / \mathrm{L}$ glucose supplemented with $10 \% \mathrm{FCS}$ and $1 \%$ glutamine. All cell lines were maintained at $37{ }^{\circ} \mathrm{C}$ in a humidified atmosphere containing $5 \% \mathrm{CO}_{2}$. Cell viability was determined by a luminescent assay according to the manufacturer's instructions (Promega, Madison, WI, USA). For $\mathrm{IC}_{50}$ determination, the cells were seeded in 96 -well plates $(3 \times 103$ cells/well) containing $90 \mu \mathrm{L}$ of growth medium. After $24 \mathrm{~h}$ of culture, the cells were treated with the tested compounds at 10 different final concentrations. Each concentration was obtained from serial dilutions in culture medium starting from the stock solution. Control cells were treated with the vehicle. 
Experiments were performed in triplicate. After $72 \mathrm{~h}$ of incubation, $100 \mu \mathrm{L}$ of CellTiter Glo Reagent was added for 15 min before recording luminescence with a spectrophotometric plate reader PolarStar Omega (BMG LabTech). The dose-response curves were plotted with Graph Prism software and the $\mathrm{IC}_{50}$ values were calculated using the Graph Prism software from polynomial curves (four or five-parameter logistic equations).

\subsubsection{Metabolization study of $\mathbf{1 5 b}$ and $\mathbf{1 5 d}$}

\subsubsection{Chemicals}

The two synthesized $\mathbf{1 5 b}$ and $\mathbf{1 5 d}$ were characterized by NMR spectroscopy and HRMS spectrometry with a HPLCUV purity of $>99 \%$.

Glucose-6-phosphate, glucose-6-phosphate dehydrogenase and nicotinamide adenine dinucleotide phosphate tetra sodium (NADPNa4) were provided by Sigma-Aldrich (St Louis, MO, USA). LC/MS-grade acetonitrile, LC/MS-grade water, methanol and formic acid were purchased from Merck (Darmstadt, Germany). Stock solutions of the two compounds were prepared at $1600 \mu \mathrm{g} / \mathrm{mL}$ (about $4 \mathrm{mM}$ ) in methanol/dichloromethane (96/4, v:v) and stored at $4{ }^{\circ} \mathrm{C}$ until the in vitro metabolism study.

\subsubsection{High performance liquid chromatography-mass spectrometry (HPLC-MS)}

HPLC-MS chromatograms were performed using an Alliance 2695 HPLC system (Waters, Milford, USA) fitted with a XBridge C18 column $(2.1 \times 150 \mathrm{~mm}, 3.5 \mu \mathrm{m})$. Gradient elution was achieved with a flow rate of $0.25 \mathrm{~mL} / \mathrm{min}$ using water with $0.1 \%$ formic acid (solvent $\mathrm{A}$ ) and acetonitrile with $0.1 \%$ formic acid (solvent B) from A:B (95/5, v:v) to A:B (0/100, v:v) in 20 min. Analytes were detected with a LCT ${ }^{\circledR}$ Premier time-of-flight mass spectrometer (Waters, Milford, USA) operating in positive electrospray ionization mode scanning from 100 to $1000 \mathrm{~m} / z$ with 10 spectra/s. MS parameters settings were: capillary and cone voltage at $3500 \mathrm{~V}$ and $25 \mathrm{~V}$. High resolution mass spectra (HRMS) were processed using MassLynx ${ }^{\circledR}$ software.

\subsubsection{High performance liquid chromatography-tandem mass spectrometry (HPLC-MS/MS)}

HPLC-MS/MS analyses were performed using a HPLC system (Ultimate 3000, Dionex, USA) fitted with a Hypersil ${ }^{\circledR}$ C18 column $(2.1 \times 100 \mathrm{~mm}, 5 \mu \mathrm{m})$ Thermo Fischer Scientific Inc, Waltham, MA, USA. Isocratic elution was achieved with a flow rate of $200 \mu \mathrm{L} / \mathrm{min}$ of the mobile phase, acetonitrile/water (60:40, v/v) with $0.2 \%$ formic acid. The total run time was $5 \mathrm{~min}$. After injection of $10 \mu \mathrm{L}$, HPLC-MS/MS analyses were performed using the LTQ-Orbitrap ${ }^{\mathrm{TM}}$ Velos Pro

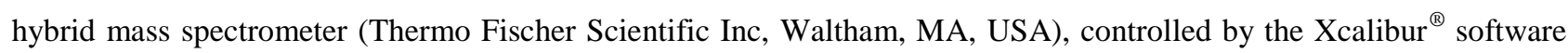
operating in positive electrospray ionization at unit mass resolution by scanning over $\mathrm{m} / \mathrm{z} 150$ to 450 using collisioninduced dissociation of the selected precursor ions. Quantification of compounds was performed by selective reaction monitoring with the following ion transitions: $m / z, 347.1 \rightarrow 332.1$ for $\mathbf{1 5 d}, \mathrm{m} / \mathrm{z} 368.1 \rightarrow 338.1$ for $\mathbf{1 5 b}$ and $\mathrm{m} / \mathrm{z}, 317.1 \rightarrow$ 302.1 for IS (isoCA-4). Collision energy was optimized at $45 \mathrm{eV}$ for $\mathbf{1 5 d}$ and at $25 \mathrm{eV}$ for $\mathbf{1 5 b}$ and isoCA-4 using helium as collision gas. HPLC-MS/MS analyses were processed using Xcalibur ${ }^{\circledR}$ software. Calibration curves of each compound were fitted with $1 / c$ weighted least-squares regression by plotting the peak area ratio of each analyte to IS against the analyte concentration over the calibration range $(1-50 \mu \mathrm{g} / \mathrm{mL}$ or $3-140 \mathrm{nM} / \mathrm{mL})$ in buffer (PH 7.4). The ESIMS parameters were set as follows: spray voltage at $3400 \mathrm{~V}$, source heater and capillary temperature at $300{ }^{\circ} \mathrm{C}$ and 350 ${ }^{\circ} \mathrm{C}$, respectively with drying gas flowrate at $40 \mathrm{~L} / \mathrm{h}$.

\subsubsection{Incubation of CH compounds with rat and human liver microsomes}

Rat liver microsomes (RLM) and human liver microsomes (HLM) were provided at a protein concentration of 20 $\mathrm{mg} / \mathrm{mL}$ by Thermofischer Scientific Inc, Waltham, MA, USA. Incubations were performed at a final protein concentration of $1 \mathrm{mg} / \mathrm{mL}$ for microsomal suspensions in $10 \mathrm{mM}$ buffer (pH 7.4). After pre-warming at $37{ }^{\circ} \mathrm{C}$, in the 
presence of a NADPH-generating system consisting in $0.6 \mathrm{mM}$ NADPNa4, $6.4 \mathrm{mM}$ glucose-6-phosphate and $2 \mathrm{U} / \mathrm{mL}$ glucose-6-phosphate dehydrogenase, the incubation started by the addition of substrate at a final $100 \mu \mathrm{M}$ concentration ( $2 \%$ of total incubation volume) and the solution was shaken at $37{ }^{\circ} \mathrm{C}$. After the incubation time of $0,1,3,6,24,48,72$, $96 \mathrm{~h}$ (up to $144 \mathrm{~h}$ ), $50 \mu \mathrm{L}$ aliquots (in triplicate) were drawn in polypropylene tubes containing $100 \mu \mathrm{L}$ of internal standard solution (isoCA-4, $2500 \mathrm{ng} / \mathrm{mL}$ acetonitrile) and mixed with $1 \mathrm{~mL}$ of ethyl acetate to stop the reaction. After centrifugation at 13,000 rpm for $4 \mathrm{~min}$. and evaporation of the recovered organic phase under vacuum centrifugation at $40{ }^{\circ} \mathrm{C}$, the residue was dissolved in $0.1 \mathrm{~mL}$ of acetonitrile and analysed by HPLC-MS/MS.

\subsubsection{Tubulin Binding Assay}

Porcine brain tubulin was isolated following Shelanski procedure.[41] Tubulin was solved in 0.1 M MES buffer, 1.5 mM GTP, $1 \mathrm{mM}$ EGTA, $1 \mathrm{mM} \beta$-ME, $1 \mathrm{mM} \mathrm{MgCl}_{2}$, pH 6.7 buffer and centrifuged at $50000 \mathrm{rpm}$ for $30 \mathrm{~min}$ in a TLA100.3 rotor (Beckman Optima TLX centrifuge). Tubulin was then diluted to $1.5 \mathrm{mg} / \mathrm{mL}$. Samples, containing the ligand or DMSO (negative control), were incubated $30 \mathrm{~min}$ at $20{ }^{\circ} \mathrm{C}$, followed by cooling on ice for 10 min. Tubulin polymerization was assessed by the UV absorbance increase at $450 \mathrm{~nm}$ (in Helios Alpha spectrophotometer, Thermo Fisher Scientific) due to the turbidity caused by a temperature shift from $4{ }^{\circ} \mathrm{C}$ to $37^{\circ} \mathrm{C}$. When a stable absorbance value was reached and maintained for at least $20 \mathrm{~min}$, the temperature was switched back to $4{ }^{\circ} \mathrm{C}$ to ascertain the return to the initial absorption values, to confirm the reversibility of the process. The degree of tubulin assembly for each experiment was calculated as the difference in amplitude between the stable plateau (absorbance at $37^{\circ} \mathrm{C}$ ) and the initial baseline of the curves (absorbance at $4{ }^{\circ} \mathrm{C}$ ). Control experiments in identical conditions but with the absence of ligand were taken as $100 \%$ tubulin polymerization. The $\mathrm{IC}_{50}$ value of tubulin polymerization was determined by measuring the tubulin polymerization inhibitory activity at different ligand concentrations. The obtained values of the mole ratio of total ligand to total tubulin in solution were fitted to mono exponential curves and the $\mathrm{IC}_{50}$ values of tubulin polymerization inhibition were calculated from the best-fitting curve of three independent experiments using Graphpad Prism 7.0 software.

\subsubsection{Cell Cycle Analysis}

Exponentially growing cancer K562 were incubated with 15d at different concentrations (0.5 and $1 \mathrm{nM})$ or in DMSO alone for $24 \mathrm{~h}$. Cell-cycle profiles were determined by flow cytometry on a FC500 flow cytometer (Beckman-Coulter, France) as described previously.[49]

\subsubsection{Mitochondrial membrane potential assay}

One of the hallmark for apoptosis is the loss of mitochondrial membrane potential $(\Delta \Psi \mathrm{m})$. The changes in the mitochondrial potential were detected by 5,5',6,6'-tetrachloro-1,1',3,3'tetraethylbenzimidazolylcarbocya-nine iodide/chloride (JC-1), a cationic dye that exhibits potential dependent accumulation in mitochondria, indicated by fluorescence emission shift from red $(590 \mathrm{~nm})$ to green $(525 \mathrm{~nm})$. In brief, K562 cells were treated with different concentrations of indole $15 \mathbf{d}$ for $48 \mathrm{~h}$. After treatment, cells were re-suspended in $1 \mathrm{~mL}$ of PBS containing $2 \mu \mathrm{M}$ final concentration JC-1 probe and incubated at $37{ }^{\circ} \mathrm{C}$ for $15 \mathrm{~min}$. Analysis of cells was performed on a FC500 flow cytometer (Beckman Coulter, France).

\subsection{Colony Formation Assays}

For colony formation assays, human chronic myeloid leukemia K562 cells (ATCC, CCL-243, Manassas, VA, USA) were cultured in Roswell Park Memorial Institute (RPMI) 1640 medium (Lonza, Basel, Switzerland), supplemented with $10 \%$ heat-inactivated fetal bovine serum (FBS) (Biowest, Riverside, CA, USA) and 1\% penicillin-streptomycin solution (100x) (GenDEPOT, Katy, TX, USA). Imatinib-resistant K562 (K562IR) cells were a gift of the Catholic University of Seoul, South Korea and cultured in RPMI 1640 medium with 25 mM HEPES (Lonza) supplemented with $10 \%(v / v)$ FCS and 1\% $(v / v)$ antibiotic-antimycotics. K562IR cells were cultured with $1 \mu \mathrm{M}$ of imatinib and washed three times before each experiment. Cells were maintained at $37{ }^{\circ} \mathrm{C}$ and $5 \%$ of $\mathrm{CO}_{2}$ in a humified atmosphere. Mycoplasma detection by Mycoalert ${ }^{\mathrm{TM}}$ (Lonza) was performed every 30 days, and cells were used within three months 
after thawing. For the colony formation assay, $10^{3}$ K562 or K562IR cells were counted and grown in a semisolid methylcellulose medium (Methocult H4230, StemCell Technologies Inc., Vancouver, BC, Canada) supplemented with $10 \%$ FBS in absence or presence of indicated concentrations of 15d. Colonies were detected after 10 days of culture by adding $1 \mathrm{mg} / \mathrm{mL}$ of 3-(4,5-dimethylthiazol-2-yl)-2,5-diphenyltetrazolium bromide (MTT) reagent (Sigma-Aldrich) and were analyzed by Image J 1.8.0 software (U.S. National Institute of Health, Bethesda, MD, USA). Data of three independent experiments are expressed as the mean \pm SD and significance was estimated by using two-way ANOVA (analysis of variance) followed by Tukey's multiple comparison test, unless otherwise stated, using GraphPad Prism 8 Software (La Jolla, CA, USA). $p$-values were considered statistically significant when $p<0.05$. Legends are represented as follows: $* p<0.05, * * p<0.01, * * * p<0.001$.

\subsection{Molecular modeling}

Atomic coordinates for tubulin $\alpha, \beta$-dimer were retrieved from the Protein Data Bank (accession code 6H9B). Missing hydrogen atoms were added using the Dock Prep module from the UCSF Chimera v1.13 software package [50], and atoms from the ligand co-crystallized in the colchicine binding at the interface between chains C and D were deleted. Coordinates for a low-energy starting conformer of compound $\mathbf{1 5 d}$ were obtained using the Conformers function from MarvinSketch v19.12 software package [51] with default parameters. Molecular docking was performed using AutoDock Vina v1.1.2 software package [52] with default parameters and the binding site defined as the box circumscribed to all the protein residues in contact with the co-crystallized ligand. Analysis and depiction of poses were performed using UCSF Chimera v1.13 software package [50].

\section{Acknowledgments}

The authors gratefully acknowledge support of this project by CNRS and University Paris-Saclay. S. Pecnard thank La Ligue contre le Cancer for its Ph.D. funding. L. Gallego-Yerga and R. Peláez acknowledge the support by the Spanish Ministry of Science, Innovation and Universities (RTI2018-099474-BI00), co-funded by the EU's European Regional Development Fund FEDER. Ji Yeon Paik and Marc Diederich thank the National Research Foundation (NRF) of Korea [Grant Number 019R1A2C1009231], the Brain Korea (BK21) FOUR program and the Creative-Pioneering Researchers Program at Seoul National University [Funding number: 370C-20160062]. Marc Diederich thanks the "Recherche Cancer et Sang” Foundation, "Recherches Scientifiques Luxembourg”, "Een Häerz fir kriibskrank Kanner”, Action Lions "Vaincre le Cancer", and Télévie Luxembourg.

\section{References}

[1] G. R. Pettit, S. B. Singh, E. Hamel, C. M. Lin, D. S. Alberts, D. Garcia-Kendall, Isolation and structure of the strong cell growth and tubulin inhibitor combretastatin A-4, Experientia 45 (1989) 209-211.

[2] A. T. Mc Gown, B. W. Fox, Differential cytotoxicity of combretastatins A1 and A4 in two daunorubicin-resistant P388 cell lines, Cancer Chemother. Pharmacol. 26 (1990) 79-81.

[3] C. M. Lin, H. H. Ho, G. R. Pettit, E. Hamel, Antimitotic natural products combretastatin A-4 and combretastatin A-2: studies on the mechanism of their inhibition of the binding of colchicine to tubulin, Biochemistry 28 (1989) 6984-6991.

[4] G.G. Dark, S.A. Hill, V.E. Prise, G.M. Tozer, G.R. Pettit, D.J. Chaplin. Combretastatin A-4, an agent that displays potent and selective toxicity toward tumor vasculature. Cancer Res. 57 (1997) 1829-1834.

[5] G. M. Tozer, V. E. Prise, J. Wilson, R. J. Locke, B. Vojnovic, M. R. Stratford, M. F. Dennis, D. J. Chaplin, Combretastatin A-4 phosphate as a tumor vascular-targeting agent: Early effects in tumors and normal tissues, Cancer Res. 59 (1999) 1626-1634.

[6] G. M. Tozer, C. Kanthou, C. S. Parkins, S. A. Hill, The biology of the combretastatins as tumour vascular targeting agents, Int. J. Exp. Pathol. 83 (2002) 21-38.

[7] Z.S. Seddigi, M.M. Shaheer, S.A. Prasanth, A.S.A. Babalghith, A.O. Lamfon, H.A. Kamal, A. Recent advances in combretastatin based derivatives and prodrugs as antimitotic agents. MedChemComm 8 (2017) 1592-1603.

[8] A. Siebert, M. Gensicka, G. Cholewinski, K. Dzierzbicka. Synthesis of Combretastatin A-4 Analogs and their Biological Activities AntiCancer Agents in Medicinal Chemistry 18 (2016) 942-960. 
[9] Y. Shan, J. Zhang, Z. Liu, M. Wang, Y. Dong. Developments of combretastatin A-4 derivatives as anticancer agents. Curr. Med. Chem. 18 (2011) 523-538.

[10] K. Ohsumi, T. Hatanaka, R. Fujita, R.Nakagawa, Y. Fukuda, Y. Nihei, Y. Suga, Y. Morinaga, Y. Akiyama, T. Tsuji, Syntheses and antitumor activity of cis-restricted combretastatins: 5-membered heterocyclic analogues, Bioorg. Med. Chem. Lett. 8 (1998) 3153-3158.

[11] S. Aprile, E. Del Grosso, G. C. Tron, G. Grosa, Identification of the Human UDP-Glucuronosyltransferases Involved in the Glucuronidation of Combretastatin A-4, Drug Metab. Dispos. 35 (2007) 2252-2261.

[12] C.-H. Shen, J.-J. Shee, J.-Y. Wu,, Y.-W. Lin, J.-D. Wu, Y.-W. Liu, Combretastatin A-4 inhibits cell growth and metastasis in bladder cancer cells and retards tumour growth in a murine orthotopic bladder tumour model. Br. J. Pharmacol. 160 (2010) 2008-2027.

[13] O. Provot, A. Hamze, J. F. Peyrat, J. D. Brion, M. Alami, Discovery and Hit to Lead Optimization of Novel Combretastatin A-4 Analogues: Dependence of C-Linker Length and Hybridization, Anti-Cancer Agents Med. Chem. 13 (2013) 1614-1635.

[14] S. Messaoudi, B. Tréguier, A. Hamze, O. Provot, J. F. Peyrat, J. R. Rodrigo De Losada, J. M. Liu, J. Bignon, J. Wdzieczak-Bakala, S. Thoret, J. Dubois, J. D. Brion, M. Alami, Isocombretastatins A versus Combretastatins A: The Forgotten isoCA-4 Isomer as a Highly Promising Cytotoxic and Antitubulin Agent, J. Med. Chem. 52 (2009) 4538-4542.

[15] R. Alvarez, C. Alvarez, F. Mollinedo, B.G. Sierra, M. Medarde, R. Pelaez, Isocombretastatins A: 1, 1-diarylethenes as potent inhibitors of tubulin polymerization and cytotoxic compounds, Bioorg. Med. Chem. 17 (2009), 6422-6431.

[16] A. Hamze, A. Giraud, S. Messaoudi, O. Provot, J. F. Peyrat, J. Bignon, J. M. Liu, J. Wdzieczak-Bakala, S. Thoret, J. Dubois, J. D. Brion, M. Alami, Synthesis, Biological Evaluation of 1,1-Diarylethylenes as a Novel Class of Antimitotic Agents, ChemMedChem 4 (2009) 1912-1924.

[17] M.A. Soussi, S. Aprile, S. Messaoudi, O. Provot, E. Del Grosso, J. Bignon, J. Dubois, J.D. Brion, G. Grosa, M. Alami. Metabolites of isoCombretastatin A-4 in Human Liver Microsomes: Identification, Synthesis and Biological Evaluation, ChemMedChem 6 (2011) 1781-1788.

[18] A. Hamze, E. Rasolofonjatovo, O. Provot, C. Mousset, D. Veau, J. Rodrigo, J. Bignon, J. M; Liu, J. Wdzieczak-Bakala, S. Thoret, J. Dubois, J. D. Brion, M. Alami, B-Ring-Modified isoCombretastatin A-4 Analogues Endowed with Interesting Anticancer Activities, ChemMedChem 6 (2011) 2179-2191.

[19] For a review on isoCA-4 analogues see: M. Alami, A. Hamze, O. Provot, Developments of isoCombretastatin A-4 Derivatives as Highly Cytotoxic Agents. Eur. J. Med. Chem. (2020), 112110.

[20] S. Messaoudi, A. Hamze, O. Provot, B. Tréguier, J. Rodrigo De Losada, J. Bignon, J.-M. Liu, J. Wdzieczak-Bakala, S. Thoret, J. Dubois, J.D. Brion, M. Alami, Discovery of Novel isoErianin Analogues as Promising Anticancer Agents, ChemMedChem 6 (2011) 488-497.

[21] E. Rasolofonjatovo, O. Provot, A. Hamze, J. Rodrigo, J. Bignon, J. Wdzieczak-Bakala, D. Desravines, J. Dubois, J. D. Brion, M. Alami, Conformationnally restricted naphthalene derivatives type isocombretastatin A-4 and isoerianin analogues: synthesis, cytotoxicity and antitubulin activity, Eur. J. Med. Chem. 52 (2012) 22-32.

[22] D. Renko, E. Rasolofonjatovo, O. Provot, J. Bignon, J. Rodrigo, J. Dubois, J. D. Brion, A. Hamze, M. Alami, Rapid synthesis of 4arylchromenes from ortho-substituted alkynols: A versatile access to restricted isocombretastatin A-4 analogues as antitumor agents, Eur. J. Med. Chem. 90 (2015) 834-844.

[23] E. Rasolofonjatovo, O. Provot, A. Hamze, J. Rodrigo, J. Bignon, J. Wdzieczak-Bakala, C. Lenoir, D. Desravines, J. Dubois, J. D. Brion, M. Alami, Design, synthesis and anticancer properties of 5-arylbenzoxepins as conformationally restricted isocombretastatin A-4 analogs, Eur. J. Med. Chem. 62 (2013) 28-39.

[24] M. Sriram, J.J. Hall, N.C. Grohmann, T.E. Strecker, T. Wootton, A. Franken, M.L. Trawick, K.G. Pinney. Design, synthesis and biological evaluation of dihydronaphthalene and benzosuberene analogs of the combretastatins as inhibitors of tubulin polymerization in cancer chemotherapy, Bioorg. Med. Chem. 16 (2008) 8161-8171.

[25] C. Herdman, T.E. Strecker, R.P. Tanpure, Z. Chen, A. Winters, J. Gerberich, L. Liu, E. Hamel, R.P. Mason, D.J. Chaplin, M.L. Trawick, K.G. Pinney. Synthesis and biological evaluation of benzocyclooctene-based and indene-based anticancer agents that function as inhibitors of tubulin polymerization, Med. Chem. Comum. 7 (2016) 2418-2427.

[26] R.P. Tanpure, C.S. George, M. Siram, T.E. Strecker, J.K. Tidmore, E. Hamel, A.K. Charlton-Sevcik, D.J. Chaplin, M.L. Trawicka, K.G. Pinney. An amino-benzosuberene analogue that inhibits tubulin assembly and demonstrates remarkable cytotoxicity, Med. Chem. Commun. 3 (2012) $720-724$.

[27] M. A. Soussi, O. Provot, G. Bernadat, J. Bignon, J. Wdzieczak-Bakala, D. Desravines, J. Dubois, J. D Brion, S. Messaoudi, M. Alami, Discovery of Azaisoerianin Derivatives as Potential Antitumors Agents, Eur. J. Med. Chem. 78 (2014) 178-189.

[28] M. A. Soussi, O. Provot, G. Bernadat, J. Bignon, D. Desravines, J. Dubois, J. D. Brion, S. Messaoudi, M. Alami, IsoCombretaQuinazolines: Potent Cytotoxic Agents with Antitubulin Activity, ChemMedChem 10 (2015) 1392-1402.

[29] I. Khelifi, T. Naret, D. Renko, A. Hamze, G. Bernadat, J. Bignon, C. Lenoir, J. Dubois, J. D.; Brion, O. Provot, M. Alami, IsoCombretaQuinolines: Novel Microtubule Assembly Inhibitors with Potent Antiproliferative Activity, Eur. J. Med. Chem. 127 (2017) 10251034.

[30] T. Naret, I. Khelifi, O. Provot, J. Bignon, H. Levaique, J. Dubois, M. Souce, A. Kasselouri, A. Deroussent, A. Paci, P. Varela, B. Gigant, M. Alami, A. Hamze, Diheterocyclic Ethylenes Derived from Quinaldine and Carbazole as New Tubulin Polymerization Inhibitors: Synthesis, Metabolism, and Biological Evaluation, J. Med. Chem. 62 (2019) 1902-1916. 
[31] I. Khelifi, T. Naret, T.; A. Hamze, J. Bignon, H. Levaique, C. Garcia, J. Dubois, O. Provot, M. Alami, N,N-bis-Heteroaryl Methylamines: Potent Anti-Mitotic and Highly Cytotoxic Agents, Eur. J. Med. Chem. 168 (2019) 176-188.

[32] For a recent review on pyrido[1,2-a] indoles see: Y. Yao, M. Alami, A. Hamze, O. Provot, Recent advances in the synthesis of pyrido[1,2a]indoles, Org. Biomol. Chem. 19 (2021), 3509-3526.

[33] C. Jimenez, Y. Ellahioui, R. Alvarez, L. Aramburu, A. Riesco, M. Gonzalez, A. Vincente, A. Dahdouh, A.I. Mansour, C. Jimenez, D.M. Rogelio, G. Sarmiento, M. Medarde, R. Pelaez, Exploring the size adaptability of the B ring binding zone of the colchicine site of tubulin with para-nitrogen substituted isocombretastatins, Eur. J. Med. Chem. 100, (2015), 210-222.

[34] T. Bzeih, T. Naret, A. Hachem, N. Jaber, A. Khalaf, J. Bignon, J.D. Brion, M. Alami, A. Hamze, A general synthesis of arylindoles and (1arylvinyl)carbazoles via a one-pot reaction from $\mathrm{N}$-tosylhydrazones and 2-nitro-haloarenes and their potential application to colon cancer, Chem. Commun. 52 (2016) 13027-13030.

[35] T. Mandal, G. Chakraborti, S. Karmakar, J. Dash, Divergent and Orthogonal Approach to Carbazoles and Pyridinoindoles from Oxindoles via Indole Intermediates, Org. Lett. 20 (2018) 4759-4763.

[36] J. Barluenga, P. Moriel, C. Valdés, F. Aznar, N- Tosylhydrazones as Reagents for Cross- Coupling Reactions: A Route to Polysubstituted Olefins. Angew. Chem. Int. Ed. 46 (2007) 5587-5590.

[37] J. An, N.J. Chang, L.D. Song, Y.Q. Jin, Y. Ma, J.R. Chen, W.J. Xiao, Efficient and general synthesis of oxazino[4,3-a]indoles by cascade addition-cyclization reactions of (1H-indol-2-yl)methanols and vinyl sulfonium salts, Chem. Commun., 47 (2011) 1869-1871.

[38] G.C. Midya, A. Kapat, S. Maiti, J. Dash, Transition-Metal-Free Hydration of Nitriles Using Potassium tertButoxide under Anhydrous Conditions. J. Org. Chem. 80 (2015) 4148-4151.

[39] A. Giraud, O. Provot, A. Hamze, J.D. Brion, M. Alami. One-pot hydrosilylation-protodesilylation of functionalized diarylalkynes: A highly selective access to Z-stilbenes. Application to the synthesis of combretastatin A-4. Tetrahedron Lett. 49, 2008, 1107-1110.

[40] This experiment (performed in triplicate) was reproduced by the same experimenter eight days apart to give the same disappointing result.

[41] M.L. Shelanski, F. Gaskin, C.R. Cantor, Microtubule Assembly in the Absence of Added Nucleotides, Proc. Natl. Acad. Sci. U.S.A. 70, 1973, $765-768$.

[42] R.B. Lichtner, A. Rotgeri, T. Bunte, B. Buchmann, J. Hoffmann, W. Schwede, W. Skuballa, U. Klar, Subcellular distribution of epothilones in human tumor cells, Proc. Natl. Acad. Sci. U. S. A., 98 (2001), 11743-11748.

[43] M. A. Jordan, K. Wendell, S. Gardiner, W. Brent Derry, H. Copp, L. Wilson, Mitotic Block Induced in HeLa Cells by Low Concentrations of Paclitaxel (Taxol) Results in Abnormal Mitotic Exit and Apoptotic Cell, Death Cancer Res., 56 (1996), 816-825.

[44] $\mathrm{IC}_{50}$ for doxorubicin against $\mathrm{K} 562$ and $\mathrm{K} 562 \mathrm{R}$ is $0.44 \mathrm{mg} / \mathrm{mL}(800 \mu \mathrm{mol} / \mathrm{L})$ and $) 6.70 \mathrm{mg} / \mathrm{mL}\left(10^{-2} \mathrm{~mol} / \mathrm{L}\right)$, respectively. See: Pan, J. Leng, X. Deng, H. Ruan, L. Zhou, M. Jamal, R. Xiao, J. Xiong, Q. Yin, Y. Wu, M. Wang, W. Yuan, L. Shao, Q. Zhang. Nicotinamide increases the sensitivity of chronic myeloid leukemia cells to doxorubicin via the inhibition of SIRT1, J. Cell. Biochem. 121, 2020, 574-586.

[45] H. Vakifahmetoglu-Norerg, A.T. Ouchida, E. Norberg, The role of mitochondria in metabolism and cell death, Biochem. Biophys. Res. Commun., 482 (2017) 426-431.

[46] J.B. Spinelli, M.C. Haigis, The multifaceted contributions of mitochondria to cellular metabolism, Nat. Cell Biol. 20 (2018) 745-754.

[47] R. Huang, Y. Sheng, Z. Xu, D. Wei, X. Song, B. Jiang, H. Chen, Combretastatin A4-derived payloads for antibody-drug conjugates. Eur. J. Med. Chem. 216, (2021), 113355.

[48] A. Maksimenko, M. Alami, F. Zouhiri, J.D. Brion, A. Pruvost, J. Mougin, A. Hamze, T. Boissenot, O. Provot, D. Desmaële, P. Couvreur, Therapeutic Modalities of Squalenoyl Nanocomposites in Colon Cancer: An Ongoing Search for Improved Efficacy, ACS Nano, 8 (2014), 2018-2032.

[49] C. Venot, M. Maratrat, C. Dureuil, E. Conseiller, L. Bracco, L. Debussche, The requirement for the p53 proline-rich functional domain for mediation of apoptosis is correlated with specific PIG3 gene transactivation and with transcriptional repression, EMBO J. 17 (1998) 4668 4679.

[50] E. F. Pettersen, T. D. Goddard, C. C. Huang, G. S. Couch, D. M. Greenblatt, E. C. Meng, T. E. Ferrin, UCSF Chimera-A visualization system for exploratory research and analysis. J. Comput. Chem. 25 (2004) 1605-1612.

[51] http://www.chemaxon.com

[52] O. Trott, A. J. Olson, AutoDock Vina: Improving the speed and accuracy of docking with a new scoring function, efficient optimization, and multithreading. J. Comput. Chem. 31 (2010) 455-461. 